\title{
Biological degradation of oil sludge: A review of the current state of development
}

\author{
Ubani, O. ${ }^{1 *}$, Atagana, H. I. ${ }^{2}$ and Thantsha, M. S. ${ }^{3}$ \\ ${ }^{1}$ Department of Environmental Sciences, University of South Africa, Pretoria, South Africa. \\ ${ }^{2}$ Institute for Science and Technology Education, University of South Africa, Pretoria, South Africa. \\ ${ }^{3}$ Department of Microbiology and Plant Pathology, University of Pretoria, South Africa.
}

Accepted 10 October, 2013

\begin{abstract}
Oil sludge is a thick viscous mixture of sediments, water, oil and hydrocarbons, encountered during crude oil refining, cleaning of oil storage vessels and waste treatment. Polycyclic aromatic hydrocarbons (PAHs), which are components of crude oil sludge, constitute serious environmental concerns, as many of them are cytotoxic, mutagenic and potentially carcinogenic. Improper management and disposal of oil sludge causes environmental pollution. The adverse effects of oil sludge on soil ecology and fertility have been of growing interest among environmental scientist and an important consideration in the development of efficient technologies for remediation of contaminated land, with a view to making such land available for further use. Oil sludge can be treated by several methods such as physical, chemical and biological processes. The biological processes are mostly cost effective and environmentally friendly, as they are easy to design and implement, as such they are more acceptable to the public. Compost, the product of biological breakdown of organic matter is a rich source of hydrocarbon-degrading microorganisms such as bacteria and fungi. These microorganisms can degrade the oil sludge to less toxic compounds such as carbon dioxide, water and salts. Compost bioremediation, the application of composting in remediation of contaminated environment, is beginning to gain popularity among remediation scientists. The success or failure of compost bioremediation depends on a number of factors such as nutrients, $\mathrm{pH}$, moisture, aeration and temperature within the compost pile. The bioavailability and biodegradability of the substrate to the degrading microorganisms also contributes to the success of the bioremediation process. This is a review on the biological remediation technologies employed in the treatment oil sludge. It further assesses the feasibility of using compost technology for the treatment of oil sludge, as a better, faster and more cost effective option.
\end{abstract}

Key words: Biodegradation, bioremediation, composting, oil sludge, polycyclic aromatic hydrocarbons (PAHs).

\section{INTRODUCTION}

Oil sludge is a thick, viscous mixture of sediments, water, oil and high hydrocarbon concentration, encountered during crude oil refining, cleaning of oil storage vessels and refinery-wastewater treatment. The chemical composition of oil sludge is complex and depends on the source. Oil sludge is mainly composed of alkanes, aromatics, asphaltenes and resin (Diallo et al., 2000). It has high content of aromatic hydrocarbons in the range

*Corresponding author. E-mail: onyedika.ubani@gmail.com. Tel: +27 78419 2899. Fax: 0862245824.

Abbreviations: PAHs, Polycyclic aromatic hydrocarbons; VOCs, volatile organic carbons; SVOCs, semivolatile organic carbons; CNS, central nervous system; PCBs, polychlorinated biphenyls; TPHs, total petroleum hydrocarbons. 
of 1 - 40 carbon atoms (US EPA, 1997).The two major sources of oil sludge are oil storage tanks and refinerywastewater treatment plants (Shie et al., 2004; Wang et al., 2010). Oil sludge found in crude oil storage tanks is typically made up of sulphides, phenols, heavy metals, aliphatic and polycyclic aromatic hydrocarbons (PAHs) of $4,5,6$ and more rings, in over 10-20 fold concentration (Li et al., 1995). More than $90 \%$ of oil sludge material is composed of paraffin, asphaltenes and aromatic hydrocarbon mixtures. Paraffins are saturated hydrocarbon (alkanes) that have the general formula $\mathrm{C}_{n} \mathrm{H}_{2 n}+_{2}$ and can either be straight chains (n-paraffins) or branched chains (isoparaffins). Asphaltenes are polycyclic aromatic clusters, substituted with varying alkyl side chain.

Aromatics hydrocarbons are unsaturated ring type (complex polycyclic of three or more fused aromatic rings) compounds, which reacts readily because they have carbon atoms that are deficient in hydrogen. All aromatics hydrocarbons have at least one benzene ring as part of their molecular structure. These components are highly recalcitrant under normal conditions. Such characteristics are attributed to their strong molecular bonds, high molecular weights, hydrophobicity and relative low solubility in water.

Oil sludge has been classified by the United States Environmental Protection Agency (US EPA) as a hazardous organic complex (US EPA, 1997; Liu et al., 2010). This contaminant enters the environment as a result of human activities, which includes deliberate dumping, improper treatments and management, storage, transportation and landfill disposal. This calls for concern because many of the oil sludge components have been found to be cytotoxic, mutagenic and potentially carcinogenic (Bojes and Pope, 2007).

The environmental impact of oil sludge contamination includes physical and chemical alteration of natural habitats, lethal and sub-lethal toxic effects on aquatics and terrestrial ecosystem. Oil sludge contains volatile organic carbons (VOCs) and semivolatile organic carbons (SVOCs) (for example, PAHs) which over the years have been reported as being genotoxic (Mishra et al., 2001; Bach et al., 2005; Bojes and Pope, 2007). They have cumulative effect on the central nervous system (CNS) leading to dizziness, tiredness loss of memory and headache, and the effect depends on duration of exposure.

In severe cases, PAH metabolism in human body produces epoxide compounds with mutagenic and carcinogenic properties that affects the skin, blood, immune system, liver, spleen, kidney, lungs, developing foetus, it also causes weight loss (TERA, 2008; API, 2008; Sidney, 2008; Bayoumi, 2009). However, environmental regulations in many parts of the world have stressed on the necessity to decrease emission of volatile organic compounds as well as PAHs, and have placed more restriction on land disposal of oil sludge (Mahmoud, 2004).

\section{SOME IMPORTANT COMPOUNDS PRESENT IN OIL- REFINERY-SLUDGE}

Some important PAHs of environmental concern present in oil sludge include Naphthalene, 1-methyl naphthalene, 2-methyl naphthalene, acenaphthylene, acenaphthene, fluorene, anthracene, phenanthrene, fluoranthene, pyrene, chrysene, benzo[a]anthracene, benzo[b]fluoranthene, benzo[k]fluoranthene, benzo[a]pyrene and indenol(1,2,3-cd)pyrene. These PAHs which may be acute or chronic hazardous organic compounds are present in substantial quantities in oil sludge and are susceptible to microbial degradation (Gibson and Subramanian, 1984; Mueller et al., 1991; Field et al., 1992; Sutherland et al., 1995). Below are the catabolic pathways by aerobic bacteria for some of the PAHs.

\section{Naphthalene}

It is an aromatic hydrocarbon, with molecular formula $\mathrm{C}_{10} \mathrm{H}_{8}$ and the structure of two fused benzene rings. Biodegradation of naphthalene involves the microbial utilization of naphthalene as described by Gibson and Subramanian (1984) and documented in a catabolic pathway as shown in Figure 1 (Ri-He et al., 2008). The initial reaction in the bacterial oxidation of naphthalene involves the formation of dihydrodiol intermediates. Bacteria oxidised naphthalene to D-trans-1, 2-dihydroxy1, 2-dihydronaphthalene (Gibson and Subramanian, 1984). Bacteria utilises a dioxygenase reaction to initiate the degradation of naphthalene, a reaction which is further catalysed by dehydrogenase to give 1, 2dihydroxynaphthalene (Gibson and Subramanian, 1984; Sutherland et al., 1995).

\section{Phenanthrene}

Phenanthrene is a polycyclic aromatic hydrocarbon composed of three fused benzene rings. Many species of bacteria found in soil are capable of utilising phenanthrene as a growth substrate. The degradation of this compound by bacteria follows an oxidative pathway (Gibson and Subramanian, 1984; Sutherland et al., 1995). Bacteria can oxidise phenanthrene to cis-1, 2dihydroxy-1,2-dihydrophenanthrene, which forms 1,2dihydrophenanthrene when it undergoes enzymatic dehydrogenation. The compounds can be oxidised further to 1-hydroxy-2-naphthoic acid, 2-carboxybenzaldehyde, o-phthalic acid, protocatechuic acid as shown in Figure 2 (Ri-He et al., 2008).

\section{Pyrene}

Pyrene is a PAH consisting of four fused benzene rings. It is the smallest peri-fused PAH (the rings are fused 


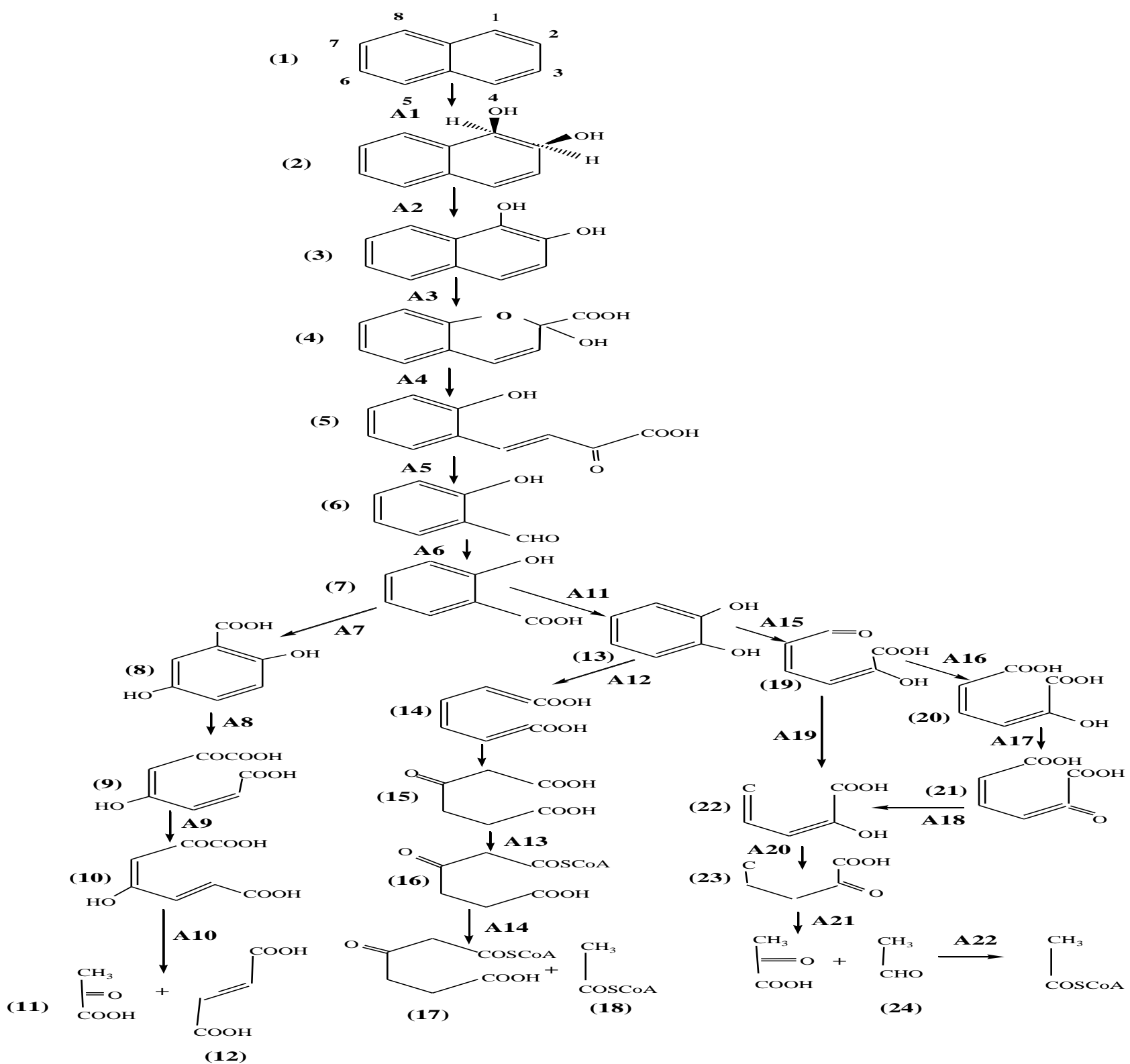

Figure 1. Proposed catabolic pathways of naphthalene by aerobic bacteria. The compounds are 1, Naphthalene; 2 , cis-1,2dihydroxy-1,2-dihydronaphthalene (cis-naphthalene dihydrodiol); 3, 1,2-dihydroxynaphthalene; 4, 2-hydroxy-2H-chromene-2carboxylic acid; 5, trans-o-hydroxybenzylidenepyruvic acid; 6, salicylaldehyde; 7, salicylic acid; 8, gentisic acid; 9 , maleylpyruvic acid; 10 , fumarylpyruvic acid; 11 , pyruvic acid; 12 , fumaric acid; 13 , catechol; 14 , cis,cis-muconic acid; 15 , $\beta$-ketoadipic acid; 16 , $\beta$-ketoadipyl-CoA; 17, succiny-CoA; 18, acetyl-CoA; 19, 2-hydroxymuconic-semialdehyde; 20, 2- hydroxymuconic acid; 21, 4oxalocrotonic acid; 22, 2-oxo-4-pentenoic acid; 23, 4-hydroxy-2-oxovaleric acid; 24, acetaldehyde. The enzymes involved in each reaction step are naphthalene dioxygenase (NahAaAbAcAd) (step A1), cis-naphthalene dihydrodiol dehydrogenase (NahB) (A2), 1,2-dihydronaphthalene dioxygenase (NahC) (A3), 2-hydroxy-2H-chromene-2-carboxylate isomerise (NahD) (A4), trans-o-hydroxybenzylidenepyruvic hydratase-aldolase (NahE) (A5), salicylaldehyde dehydrogenase (NahF) (A6), salicylate 5hydroxylase (NagGHAaAb) (A7), gentisate 1,2-dioxygenase (Nahl) (A8), maleylpyruvate isomerise (NagL) (A9), fumarylpyruvate hydrolase (NagK) (A10), salicylylate hydroxylase (NahG) (A11), catechol1,2-dioxygenase (A12), $\beta$-ketoadipate:succinyl-CoA transferase (A13), $\beta$-ketoadipyl-CoA thiolase (A14), catechol 2,3-dioxygenase $(\mathrm{NahH})(\mathrm{A} 15)$, hydroxymuconic-semialdehyde dehydrogenase (Nahl) (A16), 4-oxalocrotonate isermerase (NahJ) (A17), 4-oxalocrotonate decarboxylase (NahK) (A18), hydroxymuconic-semialdehyde hydrolase (NahN) (A19), 2-oxo-4-pentenoate hydratase (NahL) (A20), 2-oxo-4hydroxypentennoate aldolase (NahM) (A21) and acetaldehyde hydrogenase (NahO) (22) (Ri-He et al., 2008).

through more than one face). Many microorganisms have shown the capability of utilising four ringed aromatic hydrocarbons such as pyrene (Heitkamp et al., 1988b;
Meyer and Steinhart, 2001). Bacteria such as Rhodococcus sp. strain UW1 are capable of growing on pyrene as sole carbon source (Walter et al., 1991). This 


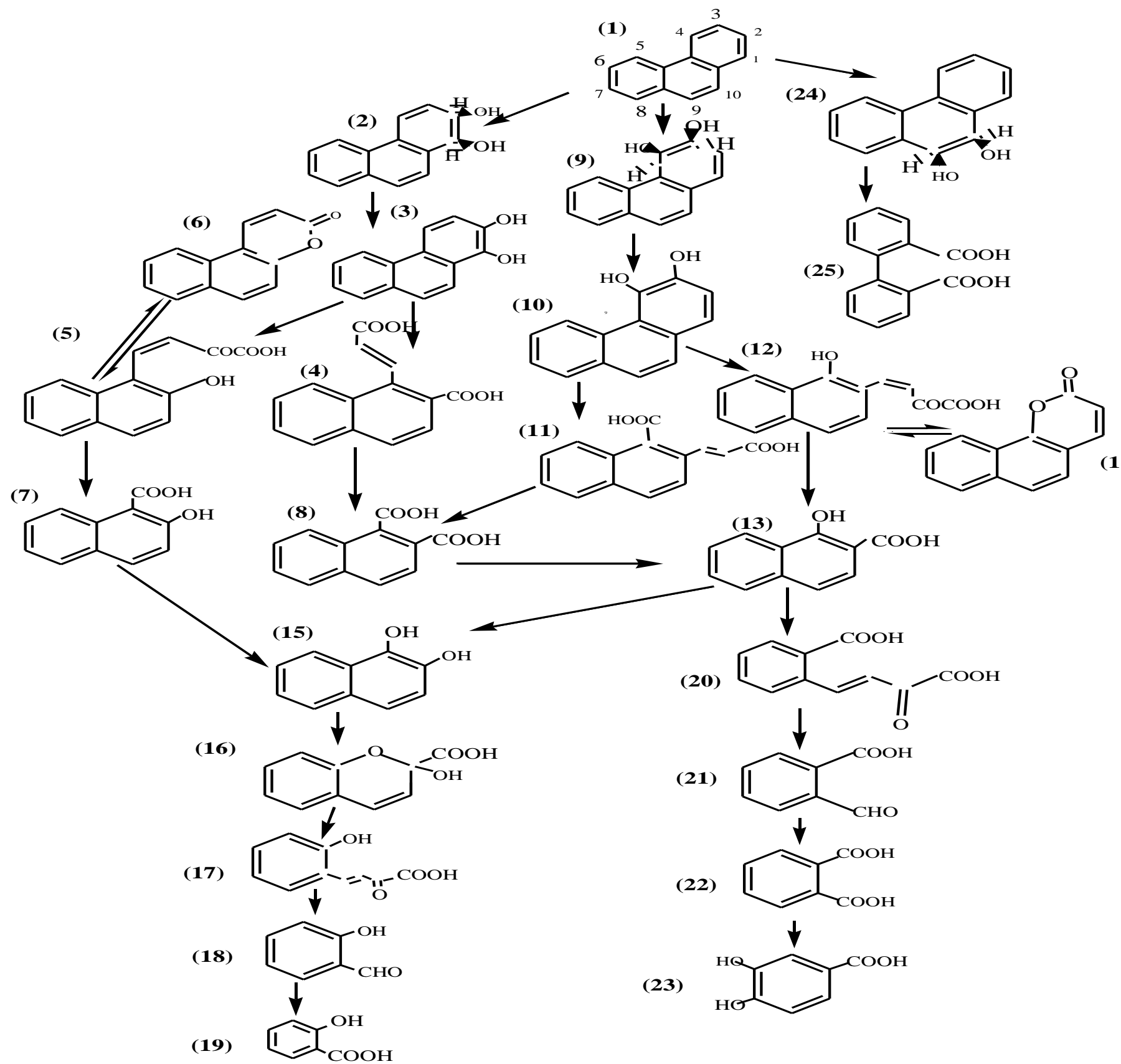

Figure 2. Proposed catabolic pathways of phenanthrene by aerobic bacteria. The compounds are 1, Phenanthrene; 2, cis -1,2-dihydroxy1,2-dihydrophenanthrene; 3, 1,2-dihydroxyphenanthrene; 4, 2-[(E)-2-carboxyvinyl]-1-naphthoic acid; 5, trans-4-(2-hydroxynaph-1-yl)-2oxobut-3-enoic acid; 6, 5,6-benzocoumarin; 7, 2-hydroxy-1-naphthoic acid; 8, naphthalene-1,2-dicarboxylic acid; 9, cis-3,4-dihydroxy-3,4dihydrophenanthrene; 10, 3,4-dihydroxyphenanthrene; 11, 1-[(E)-2-carboxyvinyl]-2-naphthoic acid; 12, trans-4-(1-hydroxynaph-2-yl)-2oxobut-3-enoic acid; 13, 1-hydroxy-2-naphthoic acid; 14, 7,8-benzocoumarin; 15, 1,2-dihydroxynaphthalene; 16, 2-hydroxy-2H-chromene2-carboxylic acid; 17; trans-o-hydroxybenzalpyruvic acid; 18, salicylaldehyde; 19, salyclic acid; 20, trans-2-carboxybenzalpyruvic acid; 21, 2-carboxybenzaldehyde; 22, o-phthalic acid; 23, protocatechuic acid; 24, cis-9,10-dihydroxy-1,2-dihydrophenanthrene; 25, 2,2'diphenic acid (Ri-He et al., 2008).

organism was found to mineralize up to $72 \%$ of pyrene to $\mathrm{CO}_{2}$ within two weeks. Three percent of the labelled carbon was found in the organic phase and $25 \%$ was present as water-soluble metabolites in the aqueous phase. Pyrene-4, 5-dihydrodiol was identified as the initial ring oxidation product and 4-phenanthroic acid as the major metabolite of the degradation of pyrene by a Mycobacterium spp (Heitkamp et al., 1988b). Also, a 


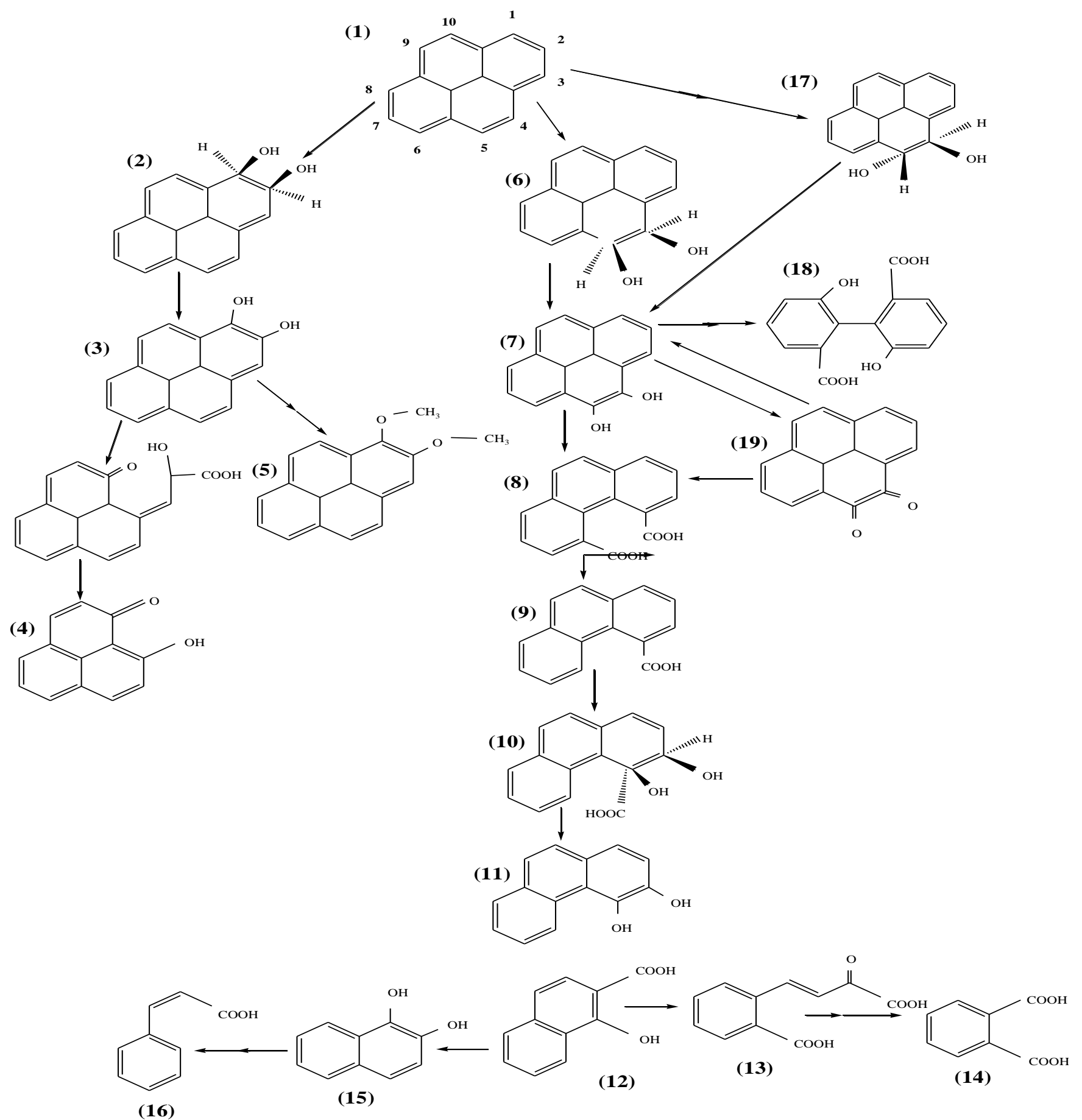

Figure 3. Proposed catabolic pathways of pyrene by aerobic bacteria. The compounds are 1, Pyrene; 2, cis-1,2-dihydroxy-1,2dihydropyrene; 3, 1,2-dihydroxypyrene; 4, 4-hydroxyperinaphthenone; 5, 1,2-dimethoxypyrene; 6, cis-4,5-dihydroxy-4,5dihydropyrene; 7, P2,4,5-dihydroxypyrene; 8, phenanthrene-4,5-dicarboxylate; 9, phenanthrene-4-dicarboxylate; 10, cis-3,4dihydroxyphenanthrene-4-carboxylate; 11, 3,4-dihydroxyphenanthrene; 12, 1-hydroxy-2-naphthoate; 13, trans-2'carboxybenzalpyruvate; 14, phthalate; 15, 1,2-dihydroxynaphtharene; 16, cinnamic acid; 17, trans-4,5-dihydroxy-4,5-dihydropyrene; 18, 6,6'-dihydroxy-2,2'-biphenyl dicarboxylic acid; 19, pyrene-4,5-dione (Ri-He et al., 2008).

proposed catabolic pathway of pyrene by aerobic bacteria has been suggested as shown in Figure 3 (Vila et al., 2001; Liang et al., 2006; Ri-He et al., 2008).

\section{Fluorene}

Fluorene is a polycyclic aromatic hydrocarbon and has 
(3)<smiles>O=C(O)I=CC(=O)C(=O)Cc1ccccc1Cc1ccccc1O</smiles>

(4)<smiles>Cc1ccccc1CC(=O)CC1(C)CC(=O)OCc2ccccc21</smiles>

(5)
(2)<smiles>CCc1ccccc1CC</smiles>
"N"<smiles>CC1=CC=CC1(C)C</smiles>

$\mathrm{OH}$<smiles>CCCCCCCO</smiles>

(6)<smiles>Cc1cccc(O)c1Cc1ccccc1</smiles>

(7)<smiles>Cc1ccccc1-c1cccc(O)c1O</smiles>

(8)

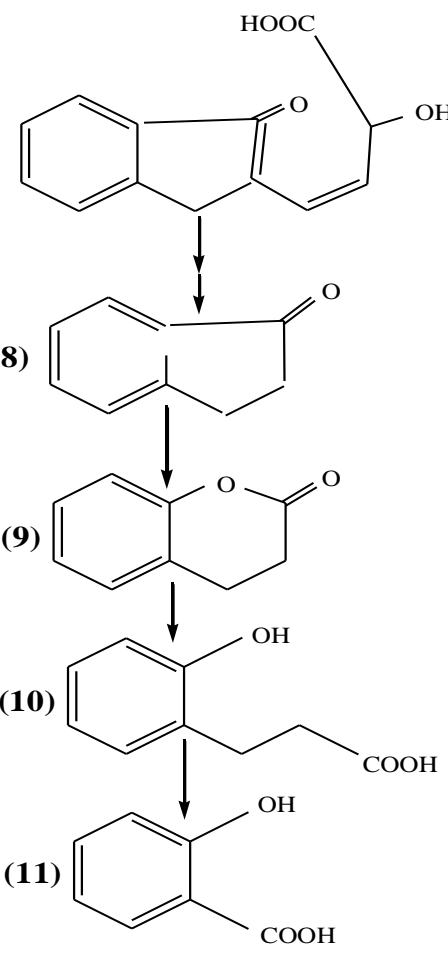<smiles>CC(C)(c1ccccc1)c1ccccc1[CH]O</smiles>

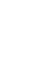

(13)

(14)<smiles>O=C1c2ccccc2-c2cccc(I)c21</smiles>

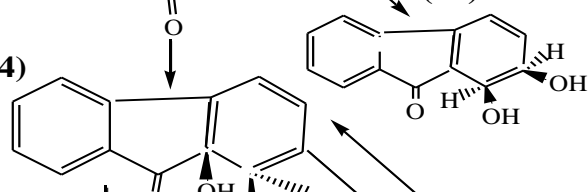

(15)<smiles>[Co][Co]</smiles><smiles>C/C=C\C=C/c1cccc(-c2ccccc2)c1O</smiles><smiles>O=c1oc2c(O)cccc2c2ccccc12</smiles>

(16)<smiles>O=C(O)c1cccc(C(=O)O)c1</smiles>



Figure 4. Proposed catabolic pathways of fluorene by aerobic bacteria. The compounds are 1, Fluorine; 2, cis-1,2-dihydroxy-1,2dihydrofluorene; 3, 1,2-dihydroxy fluorine; 4, 2-indanone; 5, 3-isochromanone; 6, cis-3,4-dihydroxy-3,4-dihydrofluorene; 7, 3,4dihydroxyfluorene; 8, 1-indanone; 9, 3,4-dihydrocoumarin; 10, 3-(2-hydroxyphenyl) propionic acid; 11, salicylic acid; 12, 9-fluorenol; 13, 9-fluorenone; 14, 1,1a-dihydroxy-1-hydro-9-fluorenone; 15, 2/-carboxy-2,3-dihydroxybiphenyl; 16, phthalic acid; 17, 4,5dihydroxyphthalate; 18, protocatechuic acid; 19, 1,2-dihydro-1,2dihydroxy-9-fluorenone; 20, 8-hydrixy-3,4-benzocoumarin (Ri-He et al., 2008).

been found to be susceptible to microbial degradation to varying extents. (Gibson and Subramanian, 1984; Mueller et al., 1991; Field et al., 1992; Sutherland et al., 1995).

The initial attack on fluorene is catalysed by dioxy- genase to yield 9-fluorenol and 1, 1a-dihydroxy-1-hydro9 -fluorenone. The catabolic pathway for fluorene degradation has been proposed as shown in Figure 4 (Kasuga et al., 2001; Wattiau et al., 2001; Habe et al., 2004; Ri-He et al., 2008). 


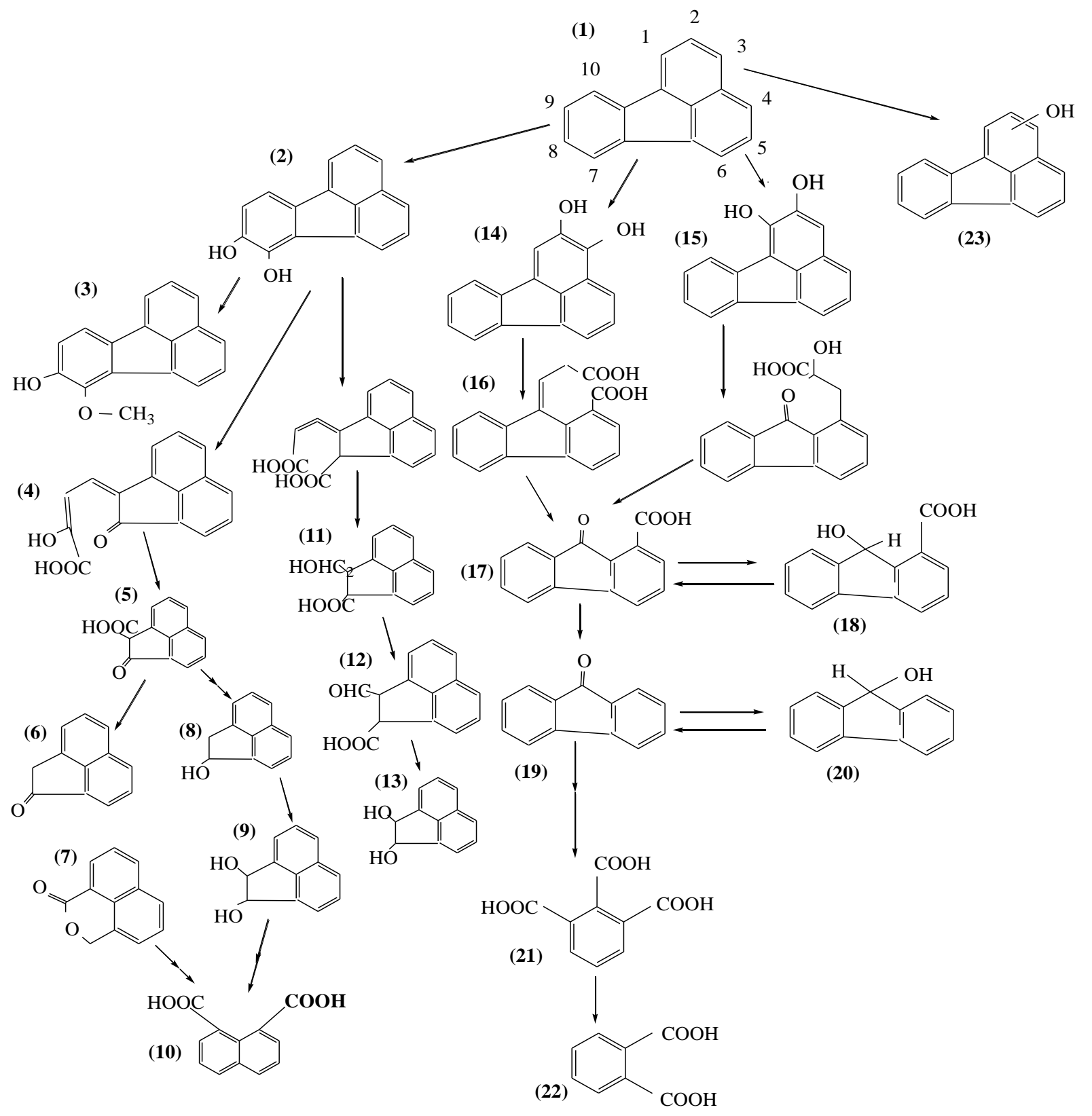

Figure 5. Proposed catabolic pathways of fluoranthene by aerobic bacteria. The compounds are 1, Fluoranthene; 2 , 7,8-dihydroxy fluoranthene; 3, 7-methoxy-8-hydroxy-fluoranthene; 4, (2Z,4Z)-2-hydroxy-4-(2-oxoacenaphthylen-1(2H)ylidene) but-2-enoic acid; 5, 1-acenaphthenone-2-carboxylic acid; 6, acenaphthylene-1 $(2 \mathrm{H})$ - one; 7,1H,3H-benzo[de] isochromen-1-one; 8, acenaphthylen-1-ol; 9, acenaphthylen-1,2-diol; 10, naphthalene-1,8-dicarboxylic acid; 11, 2(hydroxymethy)-acenaphthylene-1-carboxylic acid; 12, 2-formylacenaphthylene-1-carboxylic acid; 13, 1,2dihydroacenaphthylene-1,2-diol; 14, 2,3-dihydroxy fluoranthene; 15, 1,2-dihydroxy fluoranthene; 16, (9E)-9(carboxymethylene)-9H-fluorene-1-carboxylic acid; 17, 9-fluorenone-1-carboxylic acid; 18, 9-hydroxy-9H-fluorene-1carboxylic acid; 19, 9-fluorenone; 20, 9-hydroxyfluorene; 21, 1,2,3-benzene-tricarboxylic acid; 22, monohydroxyfluoranthene; 23, phthalic acid (Ri-He et al., 2008).

\section{Fluoranthene}

This is a polycyclic aromatic hydrocarbon consisting of naphthalene and it is a four fused benzene ring. Many microorganisms showed the capability of utilising fluoranthene (Heitkamp et al., 1988a; Meyer and Steinhart, 2001). The catabolic pathway describing the biodegradation of fluoranthene by $M$. vanbaalenii PYR-1, initiated by mono-and deoxygenated reactions has been discovered recently, Figure 5 (Ri-He et al., 2008). 


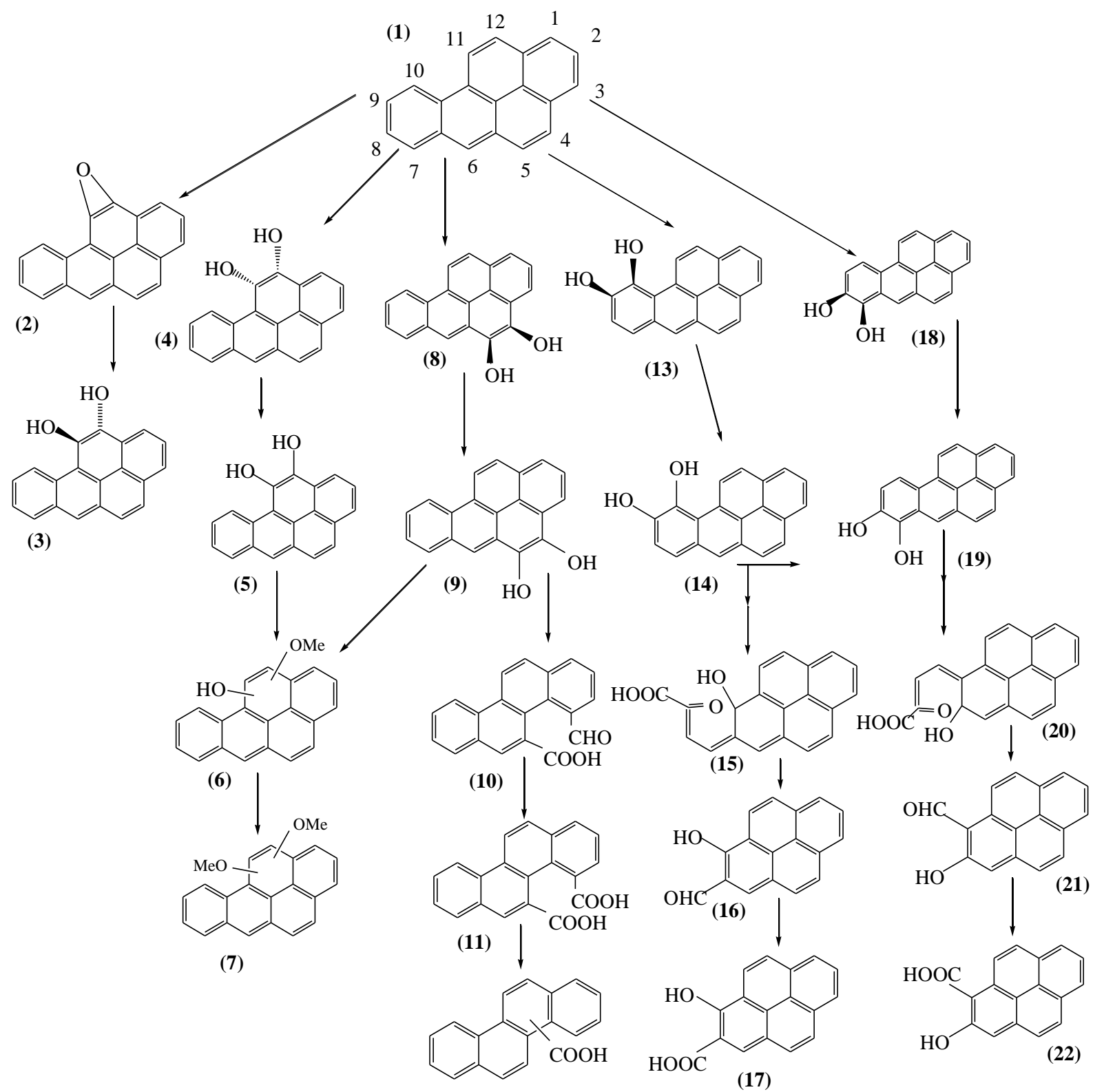

(12)

Figure 6. Proposed catabolic pathway of benzo[a]pyrene by aerobic bacteria. the compounds are 1, Benzo[a]pyrene; 2 , benzo[a]pyrene-11,12-epoxide; 3, trans-benzo[a]pyrene-11,12-dihydrodiol; 4, cis-benzo[a]pyrene-11,12-dihydrodiol; 5, 11,12-dihydroxy-benzo[a]pyrene; 6, hydroxymethoxybenzo[a]pyrene; 7 , dimethoxybenzo[a]pyrene; 8, cisbenzo[a]pyrene-4,5-dihydrodiol; 9, 4,.5-dihydroxy-benzo[a]pyrene; 10, 4-formylchrysene-5-carboxylic acid; 11, 4,5chrysene-dicarboxylic acid; 12, chrysene-4(5)-carboxylic acid; 13, cis-benzo[a]pyrene-9,10-dihydrodiol; 14, 9,10dihydroxy-benzo[a]pyrene; 15, cis-4-(8-hydroxypyrene-7-yl)-2oxobut-3-enoic acid; 16, pyrene-8-hydroxy-7-aldehyde; 17, pyrene-8-hydroxy-7-carboxylic acid; 18, cis-benzo[a]pyrene-7,8-dihydrodiol; 19, 7,8-dihydroxy-benzo[a]pyrene; 20, cis-4(7-hydroxypyrene-8-yl)-2-oxobut-3-enoic acid; 21, pyrene-7-hydroxy-8-aldehyde; 22, pyrene-7-hydroxy-8-carboxylic acid (Ri-He et al., 2008).

\section{Benzo[a]pyrene}

This is a five ring polycyclic aromatic hydrocarbon $\left(\mathrm{C}_{20} \mathrm{H}_{12}\right)$ whose metabolites are mutagenic and highly carcinogenic (Le Marchand et al., 2002). Benzo[a]pyrene can be oxidised by different microorganisms to various metabolites, which include: trans-7, 8-dihydroxy-7, 8dihydrobenzo[a]pyrene, 3-hydroxybenzo[a]pyrene and 9hydroxybenzo[a]pyrene, $\quad$ trans-9,10-dihydroxy-9,10dihydrobenzo[a]pyrene, benzo[a]pyrene-1,6-quinone, benzo[a]pyrene-3,6-quinone Figure 6 (Gibson and Subramanian, 1984; Cerniglia et al., 1992; Ri-He et al., 
(2)

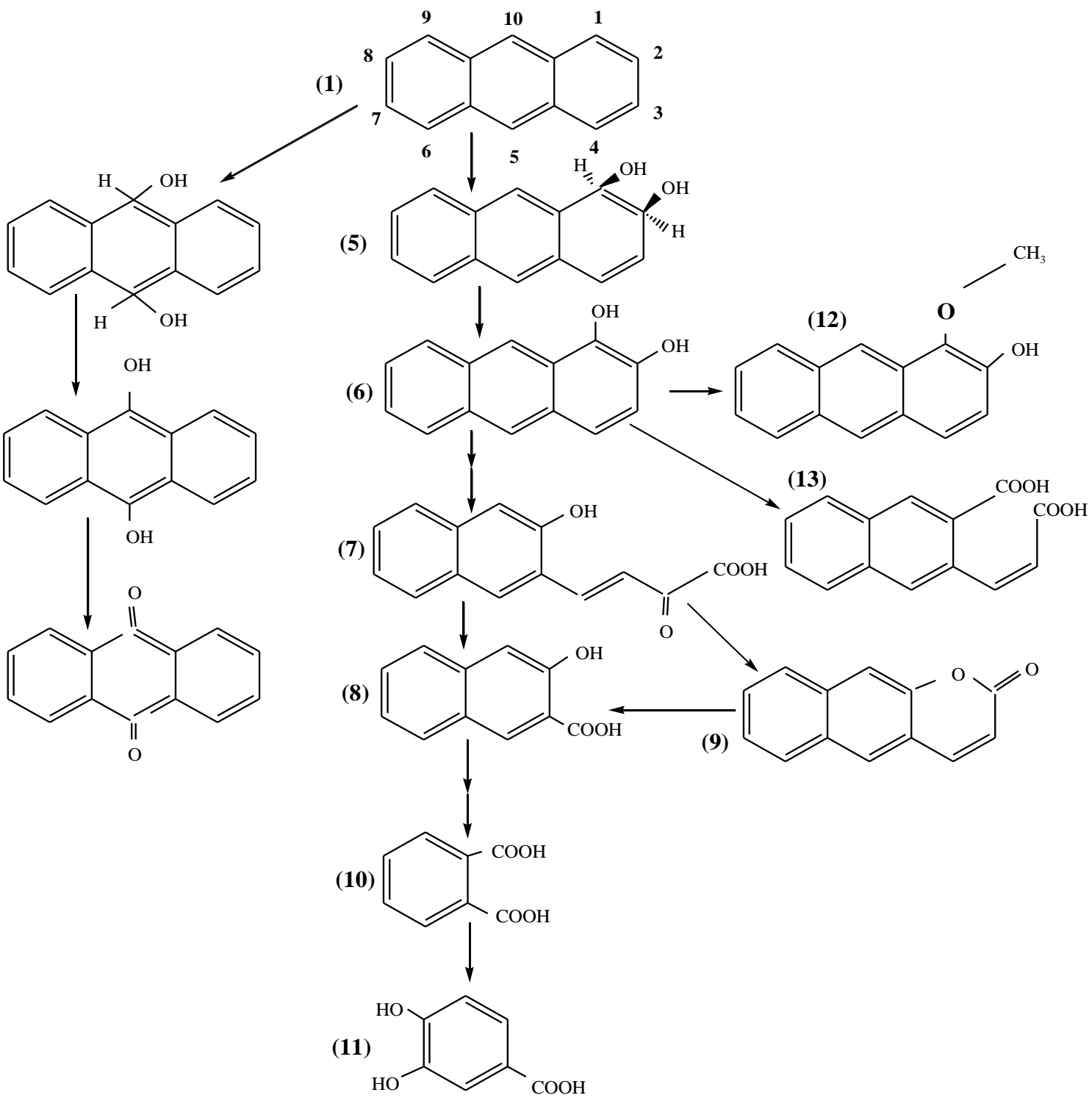

Figure 7. Proposed catabolic pathways of anthracene by aerobic bacteria. the compounds are 1, Anthracene; 2 , anthracene-9,10-dihydrodiol; 3, 9,10-dihydroxyanthracene; 4, 9,10-anthraquinone; 5, cis-1,2-dihydroxy-1,2dihydroanthracene; 6, 1,2-dihydroxyanthracene; 7, cis-4-(2-hydroxynaphth-3-yl)-2-oxobut-3-enoic acid; 8, 2-hydroxy3-naphthoic acid; 9, 6,7-benzocoumarin; 10, o-phthalic acid; 11, protocatechuic acid; 12, 1-methoxy-2hydroxyanthracene; 13, and 3-(-2carboxyvinyl)-napthalene-2-carboxylic acid (Ri-He et al., 2008).

2008).

\section{Anthracene}

This is a polycyclic aromatic hydrocarbon consisting of three fused benzene rings. It is also component of coal tar (Iglesias et al., 2010). The initial reactions in the bacterial degradation of anthracene involve the formation of trans-1, 2-dihydroxyanthracene prior to ring fission (Gibson and Subramanian, 1984).

Additional studies showed that Pseudomonas putida strain 199 and Beijerinckia sp. strain B-836 oxidised anthracene to (+)-cis-1, 2-dihydroxy-1, 2-dihydroxyanthracene. Bacteria grown in a medium of naphthalene are shown to oxidise anthracene, 1, 2-dihydroxyanthracene to 2-hydroxy-3-naphthaldehyde (Gibson and Subramanian, 1984; Sutherland et al., 1995). Also, the reactions in the degradation of anthracene are catalyzed by multicomponent dioxygenases to produce cis-1, 2dihydrodiols.

The proposed catabolic pathway involves the orthocleavage of 1, 2-dihydroxyanthracene into 3-(2carboxyvinyl) naphthalene-2-carboxylic acid for Mycobacterium sp. PYR-1 and Rhodococcus sp. Figure 7 (Dean-Ross et al., 2001; Moody et al., 2001). 


\section{Other PAHs}

The other PAHs are classified as acute/chronic toxic hazardous organic compounds. They include compounds such as benzo[a]anthracene, benzo[k]fluoranthene with five fused benzene rings and indenol (1, 2, 3-cd) pyrene with six fused benzene rings. They are present in substantial quantities in oil sludge and can also be susceptible to microbial degradation (Gibson and Subramanian, 1984; Mueller et al., 1991; Field et al., 1992; Sutherland et al., 1995).

\section{OIL SLUDGE IN THE ENVIRONMENT}

It is generally recognised that land as a component of the environment deserves the same attention and protection as water and air (Okieimen and Okieimen, 2005). This recognition has perhaps risen because of increased incidents of land pollution, the scarcity of land, awareness and concern about long-term effects of land pollution on terrestrial and aquatic ecosystems. The adverse effects of oil sludge on soil ecology and fertility have been pivotal in the development of efficient technologies for the degradation of these contaminants in the environment (Okieimen and Okieimen, 2005). As oil sludge is dumped into the environment, lighter compounds volatilize and heavier ones remain. Most oil sludge components have high affinity for soil material and particulate matter. Overtime, they accumulate to the extent that they become difficult to eliminate because they reside in fine pores. Then, they become protected from attack by biota in the soil; hence they are not bio-available. Their fate and behaviour are controlled by factors such as soil type and their physico-chemical properties (Reid et al., 2000). Such properties include their concentration, structures of the components and their solubility, environmental conditions (temperatures, $\mathrm{pH}$, moisture content and wind), and the available microorganisms (physiology and genetics). Their solubility is the key factor of their fate in the environment. The solubility of oil sludge components differs from one compound to another, some are infinitely soluble polar compounds, and others are of low solubility for example, the PAHs (Mahmoud, 2004). As the contact time with the environment increases, chemical and biological availability of the compounds decreases, a process termed "ageing", which has attracted considerable attention in recent years.

Oil sludge can be biodegraded by microorganisms such as bacteria and fungi. A large number of bacteria species have the ability to degrade majority of natural hydrocarbon components from oil sludge especially lowmolecular-weight contaminants (Ward et al., 2003). Microbial biodegradation is an effective and inexpensive approach to the degradation of petroleum hydrocarbons from oil sludge. This is possible as long as a large population of degrading microorganisms is present and the conditions encouraged the microbial growth and activities (Philips et al., 2000).

\section{MICROBIAL BIODEGRADATION OF OIL SLUDGE}

Oil sludge exhibits some biodegradable properties in the environments such as transformation, conversion or mineralisation, specific adhesion mechanisms and production of extracellular emulsifying agent by microorganisms (Leahy and Colwell 1990; Research triangle institute, 1999; Laskova et al., 2007; Paulauskiene et al., 2009). To successfully exploit the microbial degradation of oil sludge, it is imperative to understand and master the mechanism needed in order to manipulate the microbial activities.

For oil sludge containing large quantities of hydrocarbons, microorganisms must be able to use hydrocarbons as substrates (Tabuchi et al., 1998). They must be able to synthesize enzymes that can catalyse the reaction in which these contaminants are degraded to simpler, lower molecular chains and less toxic compounds $\left(\mathrm{CO}_{2}\right.$ and $\left.\mathrm{H}_{2} \mathrm{O}\right)$, through obtaining the nutrients and energy necessary for their survival in the process (Johnson and Scow, 1999). The initial step in this mechanism is the catabolism of oil sludge by bacteria and fungi, which involves the oxidation of the substrate by oxygenases, in which molecular oxygen is required.

Aerobic conditions are necessary for this route of microbial oxidation of hydrocarbons to take place (Marin Millan, 2004). Microbial bioremediation of oil sludge is dependent on a number factor which includes: characteristics of the oil sludge, microbial population present and other physic-chemical factors such as temperature, $\mathrm{pH}$ and moisture. However, the characteristics and fate of oil sludge depends on its molecular size and topology or stoichiometry (Kanaly and Harayama, 2000). The removal of low molecular weight petroleum hydrocarbons (4-ring or less), is first done through evaporation. As the molecular sizes increases, biodegradation rates become slower.

Oil sludge, albeit very slow, is susceptible to degradation by naturally occurring microflora, but this process reduces nutrient and oxygen level in soil which in turn impedes other environmental processes such as transformation or mineralisation. In order to enhance the oil sludge biodegradation processes and make it economically realistic and fast, it is necessary that the bioavailability of hydrocarbons present in the oil sludge matrix be increased. This may be done by biostimulation, which is simply the addition of nutrients to stimulate the growth and degradative capabilities of the indigenous microorganisms present (Piskonen and Itävaara, 2004). Many microbial strains are capable of degrading only specific components of oil sludge. However, oil sludge is a complex mixture of different petroleum hydrocarbon (Mac Naughton et al., 1999). Single bacterial species 
have limited capacities to degrade all the fractions of hydrocarbons presents (Loser et al., 1998). Hence, a mixture of different bacterial species that can degrade a broad range of the hydrocarbon constituents such as present in oil sludge would show more potential. Steps should be taken to ensure that the original indigenous bacterial communities be part of the regiment. Mishra et al. (2001) suggested that indigenous microorganisms isolated from a contaminated site will assist in overcoming this problem, as the microorganisms can degrade the components and have a higher tolerance to toxicity that may wipe off other introduced species.

\section{Factors affecting the biodegradation mechanisms}

There are many factors, including physical, chemical and biological that may ultimately determine the effectiveness of strategies for microbial bioremediation of oil sludge (van Hamme et al., 2003). These include: Biosurfactants, effect of $\mathrm{pH}$, nutrients, salinity, oxygen, temperature and water activity/ moisture contents, according to Micky (2006) and discussed below.

\section{Biosurfactants}

Biosurfactants are important agents that enhance the effective uptake of petroleum hydrocarbons by bacteria and fungi (Leahy and Colwell, 1990; Cort and Bielefeldt 2000a; b; Shiohara et al., 2001). Bacteria are known to produce biosurfactants, which they use to form emulsions of oil substrates (Calvo et al., 2004; Bayoumi, 2009; Liu et al., 2011; Plaza et al., 2011). Most bacterial strains can efficiently produce biosurfactant on petroleum hydrocarbon medium and in soil. The biosurfactants they produce can emulsify petroleum hydrocarbon in oil sludge so that they can be bioavailable to bacteria for biodegradation in the system. They do this by increasing the surface area of the substrates therefore, increased their solubility (Ahimou et al., 2000; Ron and Rosenberg, 2001; Maier, 2003; Mukherjee and Das, 2005). Biosurfactant production by bacteria comes with the advantage of being natural, non-toxic, biodegradable and a cost effective approach that can help in solubilisation of oil sludge hydrocarbons during biodegradation ( $\mathrm{Sim}$ et al., 1997; Calvo et al., 2004; Bayoumi, 2009; Liu et al., 2011; Plaza et al., 2011).

These biosurfactants secreted by bacteria are more effective than chemical surfactants in enhancing the solubility and biodegradation of petroleum hydrocarbons (Cybulski et al., 2003; Wong et al., 2004). The production of biosurfactant is proportional to the usage of hydrophobic PAHs substrates by the bacteria present in the system. Hydrocarbon catabolism in the environment can be enhanced by the production of biosurfactants and supplementary application of additives and bulking agents (Ward et al., 2003). Bulking agents such as com- compost will enhance metabolism of organic contaminants because they provide extra nutrients, additional carbon source and assist in retaining moisture contents of the pile (Namkoog et al., 2002).

\section{Effect of $\mathrm{pH}$}

Most oil degrading heterotrophic bacteria and fungi perform at their optimum when $\mathrm{pH}$ is neutral. However, fungi are known to be tolerant of acidic conditions (AlDaher et al., 1998). The mineralization of hydrocarbon components in the environment is generally optimal at $\mathrm{pH}$ 7 to 7.8 , thus overall biodegradation process is enhanced (van Hamme et al., 2003). The metabolic pathways for degradation differ in both fungi and bacteria (Cerniglia et al., 1979).

According to report by Sutherland (1992), fungal decomposition of PAHs may produce mutagenic intermediates (Frick et al., 1999). In such instance, liming may be used to increase the $\mathrm{pH}$ from acidic to alkaline state so that bacterial growth may be favoured than fungal growth.

\section{Nutrients}

The growth of heterotrophic bacteria and fungi depends on a number of nutrient elements, an electron acceptor and organic compound that serves as the source of carbon and energy (Adriano et al., 1999; Boettcher et al., 2001). For aerobic microorganisms, the electron acceptor is oxygen. Some microorganisms can utilise some inorganic compounds such as nitrates, sulphates, carbon dioxide, ferric iron and some organic compounds, as electron acceptors for electrons released by the oxidation of the substrate carbon source. Some bacteria and fungi also require low concentrations of some amino acids, vitamins or other organic molecules as growth factors. The absence of any of these essential elements from the environment may prevent growth and metabolism of microorganisms (Atagana, 2003). Microorganisms that degrade oil sludge are dependent on fixed forms of nitrogen $\left(\mathrm{NH}_{3}, \mathrm{NO}_{3}{ }^{-}, \mathrm{NO}_{2}{ }^{-}\right.$and organic nitrogen) to meet their nitrogen requirements.

These forms of nitrogen are frequently limiting for microbial populations in soil, ground water and surface water (Atlas, 1991). Microbial synthesis of adenosine triphosphate (ATP), nucleic acids and cell membranes require phosphorus.

For nitrogen to be available to soil microorganisms it must be, in most cases, present in inorganic form such as ammonium or nitrate (Swindell et al., 1988; Tate, 1995) while phosphorus is available in the form of orthophosphate (Alexander, 1999). According to report by van Hamme et al. (2003), nitrogen and phosphorus contents have great effects on microbial degradation of oil sludge. 


\section{Salinity}

Studies have shown that there are generally positive correlations between salinity and rates of mineralization of PAHs such as phenanthrene and naphthalene (Leahy and Colwell, 1990). However, it has been noted that hypersalinity will result in the decrease in microbial metabolic rates (Micky, 2006).

\section{Oxygen}

Aerobic biodegradation is the most effective pathway for bioremediation. This means that, the presence and concentration of oxygen is important in such process. Also, lack of aeration, in the system may be a ratelimiting parameter in the biodegradation and catabolism of hydrocarbons by bacteria and fungi (van Hamme et al., 2003).

The breakdown of oil sludge components may possibly involve the utilization of oxygenase, in which molecular oxygen is required. Great efficiency of natural microbial hydrocarbon degradation occurs mostly when oxygen is available (Ward et al., 2003). Although anaerobic degradation of PAHs by microorganisms has been shown to occur, the rates are somewhat negligible and limited to halogenated aromatics compounds such as the halobenzoates, chlorophenols and alkyl-substituted aromatic (Suflita et al., 1982; Boyd and Shelton, 1984; Angelidaki et al., 2000).

\section{Temperature}

Temperature is another important variable that has effect on oil sludge biodegradation. Microorganisms can grow at temperatures below 0 to above $100^{\circ} \mathrm{C}$ with good water supply (Atlas and Barther, 1987). Optimum temperature dictates the rate of oil sludge metabolism by microorganisms and also the pattern of the microbial community. Temperature has direct effect on the physical nature and chemical composition of the PAHs constituents (Atlas, 1981). Increases in temperature have been reported to be proportional to the solubility of contaminants and induces higher metabolic activity in a compost system (Gibb et al., 2001). When temperatures are low, PAHs tend to be more viscous and their water solubility is greatly reduced (Leahy and Colwell, 1990). Low temperature also affects microbial growth, propagation and subsequently results in decrease in the rate of degradation (Gibb et al., 2001). Low temperature also results in a decrease in enzymatic activities, which is essential for degradation of the oil components. The optimum temperature for hydrocarbon degradation has reported to be in the range of 30 to $40^{\circ} \mathrm{C}$. At temperatures above this range, enzymatic activities are inhibited as proteins denature at higher temperature
(Leahy and Colwell, 1990).

\section{Water activity/ moisture content}

According to Vinas et al. (2005), the rates at which PAHs are degraded are also determined by moisture level. The reason is that water is needed for microbial growth and enzymatic/biochemical activities (Leahy and Colwell, 1990). Elemental uptake by microorganisms is by absorption and transportation of solubilised molecules across the cell membrane. The availability of target molecules to the microorganisms depends on the amount of water present in the treatment matrix.

Optimal activity occurs when the soil moisture and water content for aerobic bioremediation treatment matrix is usually between 50 and $80 \%$ of saturation (moisture holding capacity) (Kosaric, 2001). When the moisture content falls below $10 \%$ bioactivity becomes marginal (Kosaric, 2001). However, if the soil water holding capacity is high above the optimal ranges, biodegradation rates are usually small because of possible waterlogging. The water-logging may promote anoxic conditions, thereby reducing aerobic bioremediation efficiency.

\section{TREATMENT TECHNOLOGIES AND DISPOSAL OF OIL SLUDGE}

Safe disposal and treatment of huge quantity of oil sludge generated during the processing of crude oil are some of the major challenges faced by oil refineries and petrochemical industries (Srinivasarao et al., 2011). In recent years, most refineries treat oil sludge using conventional methods which includes; physical treatment (storage, landfilling, combustion and incineration in a rotary kiln, lime stabilization, stabilization and solidification) (Wright and Noordhius, 1991; Karamalidis and Voudrias, 2001; Bhattacharyy and Shekdar, 2003; Radetski et al., 2006; Beech et al., 2009; Liu et al., 2010), chemical treatment (oxidative thermal treatment, treatment with fly-ash, pyrolysis treatment and solvent extraction) (Bonnier et al., 1980; Atlas, 1984; Taiwo and Otolorin, 2009) and biological treatment (landfarming, bio-reactor treatment and composting) (Pereira-Neta, 1987; Piotrowski, 1991; Lees, 1996; Singh et al., 2001; Hejazi et al., 2003; Mahmoud, 2004; De-qing et al., 2007; Srinivasarao et al., 2011; Udotong et al., 2011; Besalatpour et al., 2011). Most of the physical and chemical methods require expensive equipments and high energy to treat the oil sludge. Some of these methods convert oil sludge into lighter products and reduce the quantity before disposal. Some of the methods may generate by-products that may need to be treated using other methods before disposal to a landfill (Liu et al., 2010), making them more expensive. Exam- 
ples of the conventional methods used are discussed below.

\section{Incineration}

Incineration is a technology commonly used in large refineries. The common types are rotary kiln and fluidized bed incinerators. In rotary kiln incinerator, the combustion temperature is from 980 to $1200^{\circ} \mathrm{C}$ and the residence time is about $30 \mathrm{~min}$. While in fluidized bed incinerators, the combustion temperature is from 732 to $760^{\circ} \mathrm{C}$, and the residence time may be in order of days. The incineration process requires sophisticated equipments and experienced operators to achieve adequate combustion of oil sludge. Usually the incineration of oil sludge using fluidized bed technique produces ash scrubber sludge, with low contents of heavy metals. These products are usually disposed of in a landfill (Liu et al., 2010). Incineration is an expensive technique and oil sludge contains high concentration of hazardous compounds including those that are resistant to incineration. Incineration is not only expensive but generates toxic residues such as ash, scrubber water, scrubber sludges, sulphur dioxide, nitrogen monoxide, carbon monoxide and some organic compounds (Srinivasarao et al., 2011). Some of these residues such as ash containing metals need to be treated before being disposed of. During the incineration process, waste feed rates, oxygen: air ratio, residence time, combustion temperature and gas emission are critical parameters that needs to be controlled (Mahmoud, 2004).

\section{Treatment with fly-ash}

This is the treatments of oil sludge with aqueous slurry of fly-ash and a small amount of polymers. This process mixes light sludge in a small tank equipped with a mixer before thickening. Sludge with high oil and solids contents are de-watered in a centrifuge before being treated with ash slurry in a screw mixer. The settled products from the thickener and mixer are transported in closed truck containers directly to a landfill, which must be well drained to minimize leaching. During the dry season the deposit quickly become hard enough to be used for roadbeds. Sludge treated in this way may be covered with a layer of soil and the deposit area can be used to grow grass and trees (Atlas, 1984; Mahmoud, 2004). This method may be expensive, since equipments, energy and operating persons are needed for this process.

\section{Lime stabilization}

Stabilization involves mixing a solid additive material to the oil sludge in order to produce a matrix within which the oil and metal are fixed and will not leach out. The use of lime for this purpose has being established in the literature, the addition of lime produces physical and chemical changes in the oil sludge which facilitates hydrocarbon adsorption and immobilization of metals as insoluble salts (Wright and Noordhius, 1991; Mahmoud, 2004).

The high pH provided by adding the lime is essential in this process, some additives can be added to produce hydrophobic matrix to prevent contaminants from becoming acidic due to rainfall percolation in the landfill (Mahmoud, 2004).

This technique may also generate residual products that may need to be treated by using other methods before disposal in a landfill which will make the techniques expensive.

\section{Solvent extraction}

In this method, the oil sludge is extracted with a solvent to remove oil and other organics, the solvent is recovered and recycled. Many refineries believe that recycling is the most desirable environmental option for handling oil sludge, due to the possibility of recovering valuable oil for reprocessing, reformulating and energy recovery (Bonnier et al., 1980; Taiwo and Otolorin, 2009). During recycling, the condensed solvent and water are continuously separated in a trap. The condensed liquid contains water and hydrocarbon.

The hydrocarbons in condensed liquid may amount to $73.24 \%$ of the sludge, and they are both volatile and nonvolatile hydrocarbons. The solvent extraction technique has a tendency to greatly reduce sludge contaminants from 100 to $30 \%$ water and solid wastes. The method may possibly reduce the pollution effects of oil sludge on the environment with the recovery of recyclable hydrocarbons. If the optimum conditions are carefully selected, solvent extraction approach can significantly mitigate the non-compliance to standard limit of industrial discharge into the environ-ments and the permissible allowances for oil sludge.

Evaluation of the extent of sludge treatment before disposal can be done and can make significant impact on refinery and petrochemical industries. The advantage of solvent extraction techniques is that the recovery approach to oil sludge treatment explored can serve as a precursor to in-situ treatment and cleaning of oil storage facilities (Taiwo and Otolorin, 2009). It will also reduce economic losses and out of operation period, since there will be a reduction in time requirements for treatments, also the oil, water and mud can be effectively used and extraction solvents can be recycled. The limitation is the adaptation of selected solvent to the sludge treatment. Solvent extraction may not remove heavy metals such as arsenic, lead and selenium; these residues must be treated using other methods before disposal (Mahmoud, 2004; Taiwo and Otolorin, 2009). 


\section{Stabilization and solidification method}

This technology is used to minimize potential environmental impact of oil sludge by enhancing the nonleachable properties of the treated oil sludge. The treatment uses advanced chemical oxidation (Fenton's reagents) followed by stabilization and solidification with lime-clay and Portland cement-lime to yield oil sludge degradation and immobilization. In this process, PAHs and BTEX compounds are reduced after stabilization and solidification process (Beech et al., 2009). The reduction of these compounds may be due to the dilution which occurred by the addition of clay and lime, and by immobilization promoted by the lime and cement (Radetski et al., 2006). The stabilization and solidification process is cheap compared to many other technologies for treating and disposing oil sludge. This technique reduces the mobility of hazardous substance and contaminants in the environments through physical and chemical means, and can be applied ex-situ and in-situ (Karamalidis and Voudrias, 2001). If the ecotoxicity potential of oil sludge is considered, the initial waste has high toxicity in PAHs and high concentration of phenolic compounds before treatment while after treatment the final products would be less toxic, and can be reused as concrete road bed blocks (Karamalidis and Voudrias, 2001). Despite the fact that the process enables the change of the initial dangerous waste to non-dangerous waste, the mass and volume ratio of residual product increases after the treatment $(3 \mathrm{~kg}$ of waste yield $20 \mathrm{~kg}$ of commercial concrete block). In some cases, potential of oil sludge components leaching in long-term is possible. This calls for evaluation by a temporal series of leaching test to ensure environmental protection, in terms of public health and ecotoxicological perturbation of terrestrial and aquatic ecosystems (Karamalidis and Voudrias, 2001).

\section{Oxidative thermal treatment}

In this process, the oil sludge is not combusted but heated to remove organics and water from solids, the water is converted to steam to help strip off high boiling point semivolatile compounds, which can be condensed for recovery and disposal. The treatment is carried out using different concentration of oxygen at a constant heating temperature. This minimized waste and oil is recovered while producing a solid residue that meets environmental standards that are directly disposed into landfill. The flaw with this process is its high energy consumption and complex operation (Shie et al., 2004).

\section{Pyrolysis treatment}

It is a technique for recovering oil and organic liquid gas by breaking down large molecules into smaller ones. The treated sediments that met the standard land disposal restriction level are directly discharged. In pyrolysis treatment of oil sludge, the initial step produces $\mathrm{CO}_{2}$, hydrocarbons (volatile organics), water, $\mathrm{CO}$, char and tar. The next stage, char and tar are combusted to release heat which is needed for the endothermic pyrolysis reaction. The hydrocarbons consist mainly of low molecular weights paraffins and olefins $\left(\mathrm{C}_{1}-\mathrm{C}_{2}\right)$. The advantage of this process is that about $70-84 \%$ of the oil could be separated from the solids. The disadvantage of pyrolysis is that a significant amount of vacuum residue is produced during the process. The energy required in pyrolysis of oil sludge is very high because it is close to energy required to distillate diesel from crude oil. Oxidative pyrolysis of oil sludge performed with insufficient oxygen produces alkyl and alkene compounds rather than being oxidized to produce $\mathrm{CO}_{2}, \mathrm{CO}$ and $\mathrm{H}_{2} \mathrm{O}$. Therefore, oxygen is important in this technique to yield a better result (Liu et al., 2010).

After considering the limitations of physical and chemical processes in treating and disposing oil sludge, it becomes imperative to consider biological process, which have lauded as cost effective and environmentally friendly for treating contaminated environment. Biological treatment methods have numerous applications, which include the clean-up of ground water, soil, surface water and treatment of effluent from industrial process waste streams. Most biological techniques are developed as a result of simple emulation of nature and how nature does bioremediation (Okieimen and Okieimen 2005). Biological methods have been proposed as a possible remedy for oil sludge treatments. However, most biological methods are economically unsound, prone to prolonged treatment times and they are not permanent solutions (Ward et al., 2003). The observed time lag in biological treatment may be attributed to the stability of the compounds, their complex molecular structures and the ability of oil sludge components to adsorb onto sediments (Bach et al., 2005). Despite the complications, the biological methods are still considered as potential technologies for the treatment of oil sludge (Leung, 2004).

\section{BIOREMEDIATION}

Bioremediation is defined as the use of living organisms to reduce or eliminate environmental hazards resulting from accumulations of toxic chemicals or other hazardous waste (Gibson and Sayler, 1992). Bacteria are generally used for bioremediation, but fungi, algae and plants could also be used. Bioremediation is not a new technology however; perspectives on the use of bioremedial technologies to treat contaminants vary. There are three classifications of bioremediation. The first defines biotransformation as the alteration of contaminant molecules into less or non-hazardous molecules; the second defines 
biodegradation as the breakdown of organic substances into smaller organic or inorganic molecules while the third definition defines bioremediation as mineralization which is the complete biodegradation of organic materials into inorganic constituents such as $\mathrm{CO}_{2}$ or $\mathrm{H}_{2} \mathrm{O}$ (Leung, 2004). These three classifications of bioremediation can occur either in situ (at the site of contamination) or ex situ (contaminant taken out of the site of contamination and treated elsewhere) (Das and Mukherjee, 2007). There are advantages and disadvantages to both in situ and ex situ strategies. Ex situ strategies also known as 'pump and treat', removes the contaminants and places them in a contained environment. It involves excavation and transportation (relocation) from the natural or original contaminated site to elsewhere. This allows for easier monitoring and maintaining of conditions and progress, thus making the actual bioremediation process faster. However, the removal of the contaminant from the contaminated site is time consuming, costly and potentially dangerous.

By moving contaminants, the workers and the general public have increased exposure to the toxic material. In contrast, the in situ strategy does not require removal of the contaminant from the contaminated site. In-situ bioremediation method involves the treatment of contaminants at the natural or original contaminated sites without relocation. The in-situ methods include biostimulation and bioaugmentation and are usually cost effective because there is no need for excavation and transporttation, however, it is less controllable and time consuming. A major advantage of biological techniques is that the product is reusable.

Bioremediation is a promising strategy for the treatment of oil sludge. The technologies employed are naturecompatible, reliable, cheaper and easy to adopt compared to physical and chemical methods (MachinRamirez et al., 2008). The end products are usually harmless and include carbon dioxide, water and fatty acids. Bioremediation is often less disruptive and eliminates waste permanently. It reduces long term liability, and has greater public acceptance and regulatory encouragement. It can also be coupled with other physical or chemical methods (Idris and Ahmed, 2003). Bioremediation has its limitations; some chemicals are not amenable to bioremediation, for instance, heavy metals, radionuclides and some chlorinated compounds. In some cases, microbial metabolism of contaminants may produce toxic metabolites. Bioremediation therefore is a scientifically intensive procedure, which must be tailored to the site-specific conditions. There are different number of ex-situ and in-situ methods which include biostimulation, bioaugmentation, landfilling, landfarming, bioreactors, and composting.

\section{Biostimulation}

This involves the management of the natural environment to optimise the growth and activity of the natural microbial population (Crivelaro et al., 2010). The growth and activity of existing microorganisms are accelerated which may be inhibited under normal conditions in water and soil. According to Crivelaro et al. (2010), the low biodegradation efficiency observed in the treatments of oil sludge mixed with soil (landfarming, biopile and composting) are as a result of the imbalanced nutritional amendments. However, biostimulation is one of the possibilities to tackle this kind of problem since oil sludge has limited amounts of nitrogen as well as phosphates. This may be because in oil sludge, most of the nitrogen is not available since it is part of complex structures relatively inaccessible to the degrading microbial population (Crivelaro et al., 2010). In their study, Crivelaro et al. (2010), evaluated the potentials of biostimulation process using vinasse a byproduct from processed sugarcane which contains adequate nutrients such as nitrogen, phosphorus and potassium (Cortez and Brossard Perez, 1997; Carmen Baez-Smith, 2006), as the microbial stimulating nutrient agent for biodegradation of oil sludge.

The application of vinasse stimulated the activities and growth of microbial population greater in treatments with vinasse than the controls without vinasse. Furthermore, vinasse helped the microbial population to overcome the toxicity effects of oil sludge. Although, an increase in the soil microbial population was obtained with vinasse, it was not adequate to enhance the bioremediation efficiency of the oil sludge at the mineralisation level (Crivelaro et al., 2010). However, biostimulation process can enhance the activities and growth of microbial population capable of degrading oil sludge to mineralisation level. Therefore, biostimulation of indigenous degrading bacteria as a tool in bioremediation process should be encourage, because the process relies on the degrading bacteria that have already adapted to the site's conditions (Dzantor, 1999; Ausma et al., 2002; Singh and Lin, 2010). The constraints in this technique are time and limited knowledge of microbial process, since if compared with other technologies, bioremediation is a slow process. Also, favourable conditions such as temperature, $\mathrm{pH}$, nutrients and additives such as surfactants must be optimised to stimulate the microbial growth and activities during bioremediation (Atlas and Bartha, 1972; Kim et al., 2004; Mahmoud, 2004).

\section{Bioaugmentation}

This technique refers to the introduction of specialized or genetically engineered microorganisms that target specific chemical compounds. These organisms have been developed to biodegrade most common organic contaminants ranging from polychlorinated biphenyls (PCBs), organic solvents and petroleum hydrocarbons (Mehrashi et al., 2003; Atlas and Philip, 2005). The identi- 
fication of the key microorganisms that play a major role in pollutant degradation processes is relevant to the development of optimal in-situ bioremediation strategies (Abed et al., 2002; Watanabe, 2002). The use of such specialised formulations of microorganisms is often dictated whereby the indigenous bacteria cannot metabolize the contaminants concerned. It could be used if the contaminants are toxic to the naturally occurring bacteria. Introduction of specialized bacteria also may be used to increase the biological activity (Van Veen et al., 1997). The dynamic growth of a bacterial consortium on PAHs has been studied. The results showed varied individual ability of the bacterial strains to grow on PAHs. The growth was further improved by mixing the PAHs with non-ionic surfactant and optimising favourable conditions such as temperature and nutrients (fertilizer). The rates in reduction of petroleum hydrocarbon varied from 16.75 to 95\% (Lazar et al., 1999; van Hamme et al., 2003; Mishra et al., 2001). This means that some bacterial strains have the ability to degrade PAHs present in oil sludge. The results have shown that the performance of the microbial cultures is dependent on several factors including the composition of the sludge that varies depending on the type of crude oil and the source of the sludge inside the refinery (Mahmoud, 2004).

However, very little information is available about the use of microbial cultures that can be used to treat oil sludge on pilot scale and full scale studies. The limitation to successful bioaugmentation has always been attributed to poor survival of the introduced strains. The use of readily degradable substrate has been found as a limitation, due to low concentration and non biodegradability of targeted pollutants (Alexander, 1994). Again, if the soil (or the media that contains the contaminant) is heterogenous, there will be uneven flow of liquid or gas containing the nutrients or microbes, so different areas will undergo different rates of remediation.

Del'Arco and de Franca (2001) observed that various efforts have been attempted to improve the success of bioaugmentation process. Strategies that were employed to improve bioaugmentation process for the effective degradation of petroleum hydrocarbons include the use of adapted strains or the field application vector (Lajoie et al., 1994). Bioaugmentation of oil sludge may be a slow process if compared to landfarming and composting. Hence, more research needs to be conducted to stimulate the growth of microorganisms on oil sludge and improve the performance of the bioaugmentation process.

\section{Landfilling}

Landfilling is a deliberate dumping of oil sludge into land (pit) without formal treatment. It has been the most common form of sludge disposal. This process has limitations as it requires a large land area and volatile organic compounds are emitted if the oil sludge is not treated before disposal. Most times, the locations of landfill sites for oil sludge disposal have been selected according to availability of land and convenience rather than consideration of the hydro geological features of the sites. This calls for more strict legislative restrictions on landfilling (Bhattacharyya and Shekdar, 2003).

\section{Landfarming}

Landfarming involves the controlled application of the oil sludge on the land surface. This method requires tilling of the topsoil (for easy mixture with oil sludge), addition of water and addition of desired nutrient such as organic fertilizers and manures. Tilling in this process is important as it aids aeration, proper mixture of sludge and nutrient, thereby making the sludge bio-available for microbial degradation. Proper landfarming practice has minimal impact on the environment (good site appearance, absence of odour, relatively low-cost compliance with sound industrial practices and government regulation, minimal residue disposal problems and compatibility of the method with the climate, location and type of sludge treated).

Landfarming gained popularity over incineration and landfilling following its advantages such as low energy consumption, low risk of pollution of the surface and groundwater due to the immobility of hydrocarbons and metals through the soil (Hejazi et al., 2003; Besalatpour et al., 2011). Landfarming technique only lost its popularity when the USA Environmental Protection Agency (USEPA), issued the land disposal restriction conservation and recovery act (RCRA), establishing treatment standards under the land disposal restriction program (USEPA, 1997). The restriction prohibited the land disposal of untreated oil sludge. This led to treating the oil sludge to meet EPA treatment standards and making sure that there was no migration of hazardous constituents from the injection zone (Hejazi et al., 2003). However, landfarming was an acceptable disposal method as long as it is within EPA guideline that aims to minimize the possibility of wash out and groundwater contamination. Simplicity and cost-effectiveness are some of the major advantages of the technology (Hejazi et al., 2003). It is simple in that, typical equipments which are used for landfarming is used widely in the farming community and is therefore readily available.

Although, landfilling is reported as the most cost effective oil sludge treatment method, landfarming gained popularity among refineries following restrictions on landfilling oil sludge (Mahmoud, 2004). The challenges of landfarming include the release of hydrocarbon compounds (VOCs) during the application and degradation of oil sludge (greenhouse structure can help minimise emission), and its requirement of a large land area for treatment (just as in landfilling). There is also risk 
of residues such as the branched n-alkanes not degrading. There are also health related concerns as the sludge poses serious carcinogenic risks to workers during the early sludge application period (Hejazi et al., 2003).

\section{Bioreactors}

This is the use of a bioreactor process as a fermentation technology to degrade oil sludge into non-hazardous effluents with very low level of hydrocarbon (Daubaras and Chakrabarty, 1992; Oolman et al., 1996; Singh et al., 2001; Soriano and Pereira, 2002). These methods uses a naturally selected and acclimated indigenous bacterial culture supplemented with a carefully designed blend of nutrients such as nitrogen, phosphate, essential minerals and a surfactant for degradation. The design and process operating conditions of the technique promoted the growth of highly active microbial population, which rapidly converted the oil sludge components to carbon dioxide and water (Soriano and Pereira, 2002).

It was further reported that the bacteria involved are known oil-degrading bacteria such as Pseudomonas, Acinetobacter, Rhodococcus and Alcaligenes (Singh et al., 2001). In Singh et al. (2001) study, more than $90 \%$ of the total petroleum hydrocarbons contained in the oil sludge were degraded. After a successful treatment, $80 \%$ of the processed materials were disposed of and the reactor were reloaded with another batch of oil sludge using the remaining $20 \%$ left in the reactor to serve as inoculums for the next run (Singh et al., 2001; Soriano and Pereira, 2002). The analysis of the total petroleum hydrocarbons obtained from the treatment process indicated that oil sludge was treatable to non-hazardous levels (Daubaras and Chakrabarty, 1992; Oolman et al., 1996; Singh et al., 2001; Soriano and Pereira, 2002).

However, the effects of the oxygen supply on the biodegradation of PAHs was more important as increase in PAHs degradation was observed in one of the experiment by Soriano and Pereira (2002), from 1.7 to $10.2 \%$ per day with high oxygen availability and the result obtained after 21 days was very promising (Field, 1991; Salameh and Kabrick, 1992; Hahn and Loehr, 1992; Huesemann et al., 1993). The aqueous low total petroleum hydrocarbons (TPHs) can be sent to the wastewater system, solid residues can be disposed of in a landfarm, to a non-hazardous landfill, dewatered and reused in other industrial purposes (Singh et al., 2001). This technique can be used in the process recovery of recyclable oil, biodegradation of oil sludge and disposal of treated oil sludge. It also eliminates the need to spray high concentration oil sludge on large areas of land. Bioreactor processes has high rates and extent of degradation than landfarming process due the minimization of mass-transfer limitation, high organic matter biodegradation and progressive reduction in the total operational time (Soriano and Pereira, 2002). This technique controls the environmental and nutritional factors such as $\mathrm{pH}$, temperature, moisture, bioavailability of nutrients and oxygen promotes microbial growth and activity for the rapid degradation of oil sludge. The limitations faced by this technique are that it is an ex-situ process therefore, substantial cost can be incurred during excavation and transportation of oil sludge. The reactor mixer consumes energy and availability of well trained personnel is required for this method. It involves the risk of pollutant exposure and the unravelling limiting factors during bioremediation (Piotrowski, 1991; Lees, 1996). Despite their potentials, the use of bioreactors is limited and most studies have focused on synthetic residues (Field, 1991; Salameh and Kabrick, 1992; Hahn and Loehr, 1992; Huesemann et al., 1993). Also, oxygen limitation affects the contaminants consumption rates (Soriano and Pereira, 2002).

\section{Composting}

Despite decades of research, successful biological remediation of oil sludge in the environment remains a challenge. It is noticed that, there are physical, chemical and biological aspects of landfilling, landfarming and bioreactor treatments that can hamper the degradation processes of oil sludge, making them partially effective and sometimes prohibitively expensive. It is necessary to search for cheaper and environmentally friendly options that can enhance bioremediation of oil sludge. Such options should be able to take care of the limitations of the previous methods while improving oil sludge bioremediation. Therefore, composting process which involves the careful control and addition of nutrients, watering, tilling, addition of suitable microbial flora and bulking agents (wood-chips or hay) were considered an alternative option to improve the bioremediation of oil sludge (De-qing et al., 2007). The process leads to the production of carbon dioxide, water, minerals and stabilized organic matter (Pereira-Neta, 1987).

Composting is a controlled biological process of a mixture of substrates carried out by successive microbial populations combining both mesophilic and thermophilic activities. It is applied to solid and semi-solid organic waste such as nightsoil, sludge, animal manures, agricultural residues and municipal refuse, whose solid content are usually higher than five percent. The process can be classified into mechanical and non-mechanical processes (aerobic and anaerobic composting system); using technology as the key (the classification is divided into static pile or windrow, and mechanical or enclosed composting). Compost systems can be on three general bases: oxygen usage, technological approach and temperature. Oxygen usage is divided into aerobic and anaerobic. Aerobic composting involves the activity of aerobic microbes, and hence the provision of oxygen 
during the composting process. Aerobic composting generally is characterized by high temperatures, the absence of foul odours, and is more rapid than anaerobic composting. The addition of oxygen promotes bacterial and fungal growth within the compost pile. The organisms that grow in aerobic compost piles produce less methane and sulphur-based gases than in anaerobic composting, resulting in less odour. This method requires much higher maintenance, regular turning and mixing to incorporate air into the material than in anaerobic composting. Moisture loss is more likely in aerobic composting and frequent watering of the material is required. Anaerobic composting is characterized by low temperatures, the production of odorous intermediate products, and generally proceeds at a slower rate than aerobic composting. In anaerobic composting, the material stacks in layers to form an environment completely free of air within the layers. Bacteria, fungi and a higher form of bacteria, such as actinomycetes, that thrive in this environment begin to grow to breaking down the material. Anaerobic composting requires little maintenance, as there is no need to turn the material within the compost pile. The bacteria, however, produce more methane and sulphurbased gases as by-products, which can produce a strong odour. The odour indicates the composting process is progressing.

Composting could be divided with respect to the modes of operations such as batch operation and continuous or semi-continuous operation. When temperature is the basis, composting can be divided into mesophilic composting $\left(25-40^{\circ} \mathrm{C}\right)$ and thermophilic composting (50 - $65^{\circ} \mathrm{C}$ ). The main advantage of composting is waste stabilization. The biological reactions occurring during composting will convert organic wastes into stable, mainly inorganic forms. These stable inorganic forms may cause little pollution effects if discharged onto land or into a water course. The degradation of organic matter in aerobic composting system depends on the presence of oxygen. Oxygen serves two functions in the metabolic reaction; the terminal electron acceptor in aerobic respiration and as a substrate required for the operation of the class of enzymes called oxygenase (Finstein et al., 1980). Briefly, essential factors are those features of the physical, chemical, and biological background that are necessary to the establishment and proliferation of the microorganisms specific to the desired process. Five essential factors that have become key design features in recent compost technology are suitable microbial populations, aeration (oxygen availability), temperature, moisture content, and carbon availability.

Compost bioremediation relies on the mixing of primary ingredients of compost with the contaminants and oil sludge is compostable which is enhanced when bulking agents are added to the treatment process (Milne et al., 1998). As the compost matures, the pollutants are degraded by the active microflora within the mixture. It is called tailored compost (designed compost), in the sense that, it is specially made to treat specific contaminants at specific sites (US EPA, 1997). In most cases, temperature, $\mathrm{pH}$ and nutrients are the important factors. An increase in temperature in the compost pile increases solubility of contaminants and induces higher metabolic activity of the compost (Gibb et al., 2001). Oil sludge degrading bacteria and fungi performance are affected by $\mathrm{pH}$ level; while on the other hand, nutrients like nitrogen and phosphorus have great effect on microbial degradation of oil sludge constituents (van Hamme et al., 2003).

Jose et al. (2006) attempted to ascertain the efficacy of composting technology in the reduction of hydrocarbon contents of oil sludge with large total hydrocarbon content $\left(250-300 \mathrm{~g} \mathrm{~kg}^{-1}\right)$ in semiarid conditions. They designed three composting systems with open air piles, which were turned periodically over a period of 3 months. This system proved to be inexpensive and reliable. Jose et al. (2006) also studied the effect of bulking agent (wood shavings) addition on the oil sludge biodegradation and inoculation of the composting pile with pig slurry (a liquid organic fertilizer which adds nutrients and microbial biomass to the pile). The most effective treatment was composting pile with the bulking agent. Initially, hydrocarbon content was reduced by $60 \%$ in 3 months. It seems that the bulking agent encourages the diffusion of oxygen inside the pile. It also facilitates microbial developments and raising the temperature quicker. The temperature increase in the composting process may be due to the differing capacity of microorganisms to degrade the hydrocarbons. Since oil sludge contains highly degradable materials, these microorganisms accept the hydrocarbons as substrates, which enhance their activities, leading to the higher increase in temperature (Bengtsson et al., 1998; Jose et al., 2006). The reduction of petroleum hydrocarbon achieved in the compost bioremediation was $85-90 \%$ over a period of 11 months. The composting pile without a bulking agent was reduced by $32 \%$ in 3 months. The introduction of the organic fertilizer did not significantly improve the hydrocarbon degradation because it only degraded $56 \%$ of the hydrocarbon content.

Oxygen content is known to be a key factor in composting. In pile containing bulking agent, the oxygen content measured was always high after turning (10$14 \%)$. However, in piles without a bulking agent, oxygen content remained at 2-9\% (Zhou and Crawford, 1995). This result demonstrates the effectiveness of a bulking agent for fostering microbial activity during the composting process (Zhou and Crawford, 1995). The humidity of the pile maintained at $40-60 \%$ encouraged microbial activities and the biodegradation of the hydrocarbons. Low moisture level and low oxygen content explain the low temperature reached in piles without bulking agent. As time progressed, the moisture level of the piles decline and water had to be added. This proved to be difficult because the material may not 
readily absorb water due to the high hydrophobic nature of oil sludge (Zhou and Crawford, 1995). This is one of the challenges which always arise in bioremediation process involving co-composting with oil sludge.

The initial degradation of the hydrocarbons in oil sludge may possibly be catalysed by mono and dioxygenase enzymes (Britton, 1984; Singer and Finnerty, 1984). The enzymes gradually oxidise the hydrocarbons to alcohol and aldehydes in the presences of oxygen, producing acids that finally follow a metabolic pathway to produce carbon dioxide $\left(\mathrm{CO}_{2}\right)$ and water $\left(\mathrm{H}_{2} \mathrm{O}\right)$ (Britton, 1984; Singer and Finnerty, 1984). This is synthesized by aerobic microorganisms, which is clearly the benefit from the addition of the bulking agent. Therefore, the addition of suitable bulking agent improves aeration and the performance of the composting process of the oil sludge. When the total hydrocarbons present in the composting undergo a great degree of degradation, the process results in detoxification of the mass and the loss of their toxic substances.

The limiting step of composting process is maintaining a suitable level of humidity in the pile. Furthermore, the challenges of composting bioremediation are the nature of the oil sludge, the composting conditions, microbial communities and time. Lack of sufficient readily decomposable organic matter may give inadequate substrate to stimulate microorganisms in the decomposition of untreated disposed oil sludge (Cole et al., 2003; Fountoulakis et al., 2009). In many cases, during composting process, organic material degrades along with target organic compounds and this has been found to interfere with degradation results, therefore, complicating understanding of the treatment efficiency (Kriipsalu et al., 2007). Also during composting, if the degradation rate of target compound is slower than the biodegradable organics added as amendments; then the relative concentration of the contaminants may be affected by the reduction of the dry mass content, transformed into $\mathrm{CO}_{2}$ and $\mathrm{H}_{2} \mathrm{O}$ (Kriipsalu et al., 2007). Similar phenomenon has been described for heavy metals remaining in composting piles meanwhile the organic degrade (Parẻ et al., 1999; Kriipsalu et al., 2007). All these affect the mechanism of conversion in compost. Composting bioremediation tends to treat oil sludge in a cost-effective and environmental friendly way by utilizing effectively its biological, physical and chemical process. Many factors are considered in the design of an optimal oil sludge treatment process. These factors include time, nutrients, $\mathrm{pH}$, moisture and microbial biodegraders; they are also considered as attributes of composting processes.

Amidst limitations that may hamper the composting processes, co-composting techniques for bioremediation of oil sludge have its advantages. It is economically sound, natural process that destroys organic contaminants and the residues obtained are no more harmful. The process eliminates the transfer of residue from one from one environmental medium to another. The biological reactions occurring during composting will convert organic wastes into stable, mainly inorganic forms. These stable inorganic forms may cause little pollution effects if discharged onto land or into a water course. As already stated, composting could be ex situ or in situ process depending on whether the oil sludge is taken out from its source or not. It is often less expensive and disruption is minimal. It eliminates waste permanently, eliminates long term liability, and has greater public acceptance, with regulatory encouragement, it can also be coupled with other physical or chemical methods. As far as the effectiveness of the by-products is concerned, the treated sludge is found enriched in organic matter along with sufficient amount of nutrients (nitrogen, phosphorus and potassium). This technique does not only reduce the PAHs concentrations, but tends to improve soil quality through the addition of organic matters. Also, if compared to landfill or landfarming and destructive treatment methods, such as incineration, the use of composted material and co-composting as bioremediation technique may possibly promote soil sustainability and re-use.

It is reported in the literature that animal manure cocomposted with oil sludge can enhance the degradation of oil sludge. Also composting and the use of compost for the bioremediation of oil sludge have been reported to be cost-effective and environmental friendly. Hence, this technique has some physical, chemical and biological limitations. Such limitations can be addressed by applying the current findings as the way forward on biodegradation and bioavailability of oil sludge constituents to the degrading bacteria.

It also addresses the partitioning of oil sludge between environmental media, genetic transfer of the biodegradation knowledge to indigenous microbial communities and impact of oil sludge constituents on soil microbial diversity. These findings and knowledge on biodegradation and bioavailability of oil sludge add on the advantages that have been reported about composting techniques. Stimulated biological process and cometabolism of recalcitrant (heavy molecular weight PAHs) will be an added advantage of the composting technique. Therefore, it is important to implement the technique in such a way that takes care of all the limitations.

Amidst limitations that may hamper the composting processes, co-composting techniques for bioremediation of oil sludge have its advantages. The technique has not only reduced the PAHs concentrations, but tends to improve soil quality through the addition of organic matters. However, if compared to landfill or landfarming and destructive treatment methods, such as incineration, the use of composted material and co-composting as bioremediation technique may possibly promote soil sustainability and re-use. The reports described in this study, have shown that co-composting of oil sludge with compost materials can promote degradation of oil sludge. 
As the addition of mature/ripe compost or any other nutrients constituents to the composting processes can also enhance the biodegradation of oil sludge and can reduce the toxicity of oil sludge. In all, there must be precautions to bear in mind. The precautions must be applied where there is a comparison between a laboratory, pilot and field studies. This is because the chemical behaviour of the oil sludge constituents present may be different in each of the studies. The study may give false results different from the laboratory to that of the field studies, where the conditions are not the same. Such results may possibly lead to expectations that may not be reached at the end of the process. However, composting bioremediation tends to treat oil sludge in a cost-effective and environmental friendly way, by utilizing the removal efficiencies of its biological, physical and chemical process. It is possibly through conversion of the oil sludge to $\mathrm{CO}_{2}$ and $\mathrm{H}_{2} \mathrm{O}$. However, this aim may not be thoroughly achieved due to the limitations of the technique or the design applied. In many cases, an important fraction of the oil sludge and their metabolites remain untouched by the treatment process. The amount of oil sludge residue remaining constitutes a major concern and source of debate in relation to risk assessment. Therefore, it is recommended that as composting techniques 'rely' on the biological process to remove or reduce the hydrocarbon content of oil sludge. There is a need to first gather and put into considerations all the information about the subsequent limiting factors during bioremediation (biological, chemical and physical limitation associated with composting), while looking for a way forward in the biotreatability studies. The limiting factors should help in the choice to design the process to optimise the treatment of oil sludge even after the removal of easily degradable constituents such as 2,3 and 4 ringed $\mathrm{PAHs}$.

These limiting factors (time, nutrients, $\mathrm{pH}$, moisture level, biodegraders, toxic metabolites), during composting processes should be investigated, considered, adequately addressed and managed to optimise the biodegradation of both low and high molecular weight PAHs. Optimised biodegradation can be achieved by first conducting the laboratory and pilot studies before applying the technology to the full scale. Such strategy will reveal the information about the type and metabolic activities of the indigenous bacteria, the presence of possible inhibitors, biodegradability of oil sludge under optimal conditions, effects of nutrients and bioavailability of oil sludge in the co-compost process. The pilot study may possibly help to decide whether biostimulation, bioaugmentation or the combination of both is the relevant method for addressing the limiting factors that may occur during composting bioremediation of oil sludge. Most importantly, there is need to really understand microbial processes and environmental conditions conducive for seeding biodegradation information to the indigenous microbial communities.

\section{CONCLUSION}

In conclusion, it is evident that researchers and most refineries have tried to treat oil sludge using conventional methods which includes physical treatment (storage, landfilling, combustion and incineration in a rotary kiln, lime stabilization, stabilization and solidification) chemical treatment (oxidative thermal treatment, treatment with flyash, pyrolysis treatment and solvent extraction) and biological treatment (landfarming, bio-reactor treatment and composting).

However, safe disposal and treatment of huge quantity of oil sludge generated during the processing of crude oil have been the major challenges faced by oil refineries and petrochemical industries. This is because these methods may require expensive equipments and high energy to treat the oil sludge. Although, some of these methods convert oil sludge into lighter products and reduce the quantity before disposal but some of the methods may generate by-products that may need to be treated using other methods before disposal to a landfill, making their cost significantly higher. Nevertheless, this paper has reviewed the current position in the composting of oil sludge, the extent of development in methodology, the successes and the challenges encountered.

The pathways of aerobic transformation have been reported and it is established that microorganisms capable of degrading oil sludge could be found in the contaminated environments. This have been of growing interest to the potential use of microbes to degrade oil sludge and more recent work has established that it is possible to use microbial-based processes to remediate contaminated environments. It is clearly evident from the review that substantial progress has been made in the development and application of biological techniques in the degradation of oil and oil sludge in the environment. However, application of these technologies to the degradation of relatively complex organic substrates has continued to be a challenge. In all, bioremediation of oil sludge is feasible given the depth of our current knowledge. Although the inherent limitations of bioremediation of oil sludge are known, further research is required to test these limitations and to exploit the potential of the in-situ microbial communities to metabolise the oil sludge.

The findings will also help to deeply understand the microbial ecology and their activities in the degradation of oil sludge. It was necessary for further improvement of compost bioremediation process.

\section{ACKNOWLEDGEMENT}

The authors wish to acknowledge the financial support given by the South African National Research Foundation for this project. 


\section{REFERENCES}

Abed MMR, Safi NMD, Koster J, deBeer D, El-Nahhal Y, Rullkotter J, Garcia-Pichel F (2002). Microbial diversity of heavily polluted microbial mat and its community changes following degradation of petroleum compounds. Appl. Environ. Microbiol. 68(4):1674-1683.

Adriano DC, Bollag JM, Frankenberger Jr WT, Sims RC (1999). Bioremediation of contaminated soil. Agronomy, No.37, American Society of Agronomy.

Ahimou F, Jacques P, Deleu M (2000). Surfactin and Iturin A effects on Bacillus subtilis surface hydrophobicity. Enzyme Microb. Technol. 27:749-754.

Al-Daher R, Al-Awadhi N, El-Nawawy A (1998). Bioremediation of damaged desert environment with the windrow soil pile system in Kuwait. Environ.Int. 24:175.

Alexander M (1994). Biodegradation and bioremediation. Academic Press Inc. California.233.

Alexander M (1999). Biodegradation and Bioremediation. Academics Press, San Diego.

Angelidaki I, Mogensen AS, Ahring BK (2000). Degradation of organic contaminants found in organic waste. Biodegradation 11:377.

API (2008). The Relationship between the Aromatic Ring Class Content and Selected Endpoints of Repeat-dose and Developmental Toxicity of High-boiling Petroleum Substances. PAC Analysis Task Group. American Petroleum Institute. Washington, DC.

Atagana HI (2003). Bioremediation of creosote- contaminated soil by microbial intervention. A PhD thesis submitted to the Department of Microbiology, University of Natal, Pietermaritzburg, South Africa.

Atlas RM (1981). Microbial degradation of petroleum hydrocarbons: An environmental perspective. Microbiol. Rev. 45:180.

Atlas RM (1991). Microbial degradation of petroleum hydrocarbons: An environmental perspective. Microbiol. Rev. 45:180.

Atlas RM, Bartha R (1972). Degradation and mineralization of petroleum in sea water: limitation by nitrogen and phosphorus. Biotechnol. Bioeng. 14(3):308-318.

Atlas RM, Bartha R (1987). Microbial ecology :Fundamentals and Application. Benjamin/Cummings Publishing company. MenloPark, California.

Atlas RM, Philip J (2005). Bioremediation: Applied microbial solutions for real-world environmental cleanup. ASM Press, Wasington, D.C. 1292.

Ausma S, Edwards GC, Fitzgerald-Hubble CR, Halfpenny-Mitchell L, Gillespie TJ, Mortimer WP (2002). Volatile hydrocarbon emissions from a diesel fuel contaminated soil bioremediation facility. J. Air Waste Manage. Assoc. 52:769-780.

Bach QD, Kim SJ, Choi SC, Oh YS (2005). Enhancing the intrinsic bioremediation of $\mathrm{PAH}$-contaminated anoxic estuarine sediments with biostimulating agents. J. Microbiol. 43:319.

Bayoumi RA (2009). Bacterial bioremediation of polycyclic aromatic hydrocarbons in heavy oil contaminated soil. J. Appl. Sci. Res. 5 (2):197-211.

Beech JF, Elder S, Weeks N (2009). Case-study: Use of circulating fluidized bed boiler by- product to solidify oil sludge. World of coal ash (WOCA) conference may 4-7, in Lexington, KY, USA.

Bengtsson A, Quednau M, Haska G, Nilzen P, Persson A (1998). Composting of oil sludges-degradation, stabilized residues, volatiles and microbial activity. Waste Manage. Res. 3:273-284.

Besalatpour A, Hajabbasi MA, Khoshgoftarmanesh AH, Dorostkar V (2011). Landfarming process effects on biochemical properties of petroleum-contaminated soils. Soil and sediment contamination. 20:234-248.

Bhattacharyya JK, Shekdar AV (2003). Treatments and disposal of refinery sludges: Indian scenario. Waste Manage Res. 21:249-261.

Boettcher G, Nyer EK, Palmer PL, Carman EP, Bedessem J, Kidd DF, Lenzo F, Rorech GJ, Crossman TL (2001). In-Situ bioremediation. Insitu Treatment Technology, Second Edition CRC Press.

Bojes HK, Pope PG (2007) Characterization of EPA's 16 priority pollutant polycyclic aromatic hydrocarbons (PAHs) in tank bottom solids and associated contaminated soils at oil exploration and production sites in Texas. Regul Toxicol Pharmacol. 47(3):288-295

Bonnier PE, Akoun GL, Cardon EC, Edwards ED, Hocknel W, Holtari U, Leygue G, Long DV, Moorse JH, Peterse JL, De Roocker A, Levi JD
(1980). Sludge farming: A technique for the disposal of oil refinery waste, the oil companies' European association for environment, health and safety in refining and distribution (CONCAWE) report no. $3 / 80$

Boyd SA, Shelton DR (1984). Anaerobic biodegaradation chlorophenols in fresh and Acclimated sludge. Appl. Environ. Microbiol. 47:272.

Britton LN (1984). Microbial degradation of aliphatic hydrocarbons. In: Gibson D T (eds) Microbial degradation of organic compounds. Marcel Dekker, New York. 89-129.

Calvo C, Toledo FL, Gonzalez-lopez J (2004). Surfactant activity of a naphthalene degrading Bacillus pumilus strain isolated from oil sludge. J. Biotechnol. 109, 255-262.

Carmen Baez-Smith PE (2006). Anaerobic digestion of Vinasse for the production of methane in the suger-cane distillery, SPRI conference on sugar processing, smith-baez consulting inc, Loxahatchee, florida, USA.

Cerniglia CE, Herbert RL, Dodge RH, Szaniszlo PJ, Gibson DT (1979). Some approaches to studies on the degradation of aromatic hydrocarbons by fungi, In: Bourquin $\mathrm{AL}$ and Pritchard $\mathrm{H}$ (eds), Microbial degradation of pollutants in marine Environments. EPA Report No. EPA-600/9-79-012.EPA, Washington, DC.

Cerniglia CE, Sutherland JB, Crow SA (1992). Fungal metabolism of aromatic hydrocarbon. In: Winkelmann G (ed) Microbial degradation of natural products $\mathrm{VCH}$ press, Weinhein, 193-217.

Cole JR, Chai B, Marsh TL (2003). The ribosomal database project (RDP - II): Previewing a new autoaligner that allows regular updates and the new prokaryotic taxonomy. Nucleic Acids Res. 31:442 - 443.

Cort T, Bielefeldt A (2000). Effects of surfactants and temperature on PCP biodegradation. J. Environ. Eng. 126:635-643.

Cort T, Bielefeldt A (2000). Mechanism of non-ionic surfactant inhibition of pentachlorophenol biodegradation. In proceeding of the 2000 conference on hazardous waste research, Denver, Colorado, USA. May 23-25, 2000.

Cortez, L.A.B., L.E. Brossard Perez. Experiences on vinasse disposal. Part III:Combustion of vinasse \#6 fuel oil emulsions. Mar. 1997. São Paulo, Brazil. Br. J. Chem Eng. 14:1

Crivelaro SHR, Mariano AP, Furlan LT, Gonçalves RA, Seabra PN, Angelis DF (2010). Evaluation of the use of vinasse as a biostimulation agent for the biodegradation of oily sludge in soil. Int. J. Brazil Biol Technol. 53(5):1217-1224.

Cybulski Z, Dziurla E, Kaczorek E, Olszanowski A (2003). The influence of emulsifiers on hydrocarbon biodegradation by Pseudomondacea and Bacillacea strains. Spill Sci. Technol. Bull. 8:503-507.

Das K, Mukherjee AK (2007). Crude petroleum-oil biodegradation efficiency of Bacillus subtilis and Pseudomonas aeruginosa strains isolated from a petroleum-oil contaminated soil from North-East India. Biores. Technol. 98:1339-1345.

Daubaras D, Chakrabarty AM (1992). The environment, microbes and bioremediation: Microbial activities modulated by the environment. Biodeg. 3:125-135.

Dean-Ross D, Moody JD, Freeman JP, Doerge DR, Cerniglia CE (2001). Metabolism of anthracene by a Rhodococcus species. FEMS Microbiol Lett. 204:205-211.

Del'Arco JP, de Franca FP (2001). Influence of oil contamination levels on hydrocarbon biodegradation in sandy sediments. Environ. Pollut. 112:515-519.

De-qing S, Jain Z, Zhao-long G, Jian D, Tian-Li W, Murygina V, Kalyuzhnyi S (2007). Bioremediation of oil sludge in shengli oilfield. Water Air Soil Pollut. 185:177 - 184.

Diallo M, Cagin T, Faulon JL, Goddard WA (2000). Thermodynamic properties of asphaltene: A predictive approach based on computer assisted structure elucidated and atomistic simulations. In: Asphaltene and asphalts II (eds TF Yen and GV Chilingarian), developments in petroleum science 40B, Elsevier Amsterdam. 103127.

Diehl SV, Borazjani H (1998). Enhanced biodegradtion of organic woodpreservative contaminated wastewater by commercial surfactants. In RA Meyers (ed), Encyclopedia of environmental analysis and remediation. 3436-3451.

Dzantor EK (1999). Bioremediation of contaminated soil- what it is and how to do it. University of Agriculture and Natural Resources. 10071019. 
Field SD (1991). Advanced biological treatment and separation of hazardous constituents from petrolchemicals sludges. J. Hazard. Mat. 28:101-113.

Field JA, De Jong E, Costa GF, de Bont JAJ (1992). Biodegradation of polycyclic aromatic hydrocarbons by new isolates of white rot fungi. Appl. Environ. Microbiol. 58(7):2219-2226.

Finstein MS, Morris MI, Storm PF (1980). Microbial ecosystem responsible for anaerobic digestion and composting. J. Water. Pollut. Control Fed. 52:2675-2685.

Fountoulakis MS, Terzakis S, Georgaki E, Drakopoulou S, Sabathianakis I, Kouzoulakis M, Manios T (2009). Oil refinery sludge and green waste simulated windrow Composting. Biodegradation 20:177-189.

Frick CM, Farrel RE, Germida JJ (1999). Assessment of phytoremediation as an in-situ technique for cleaning oilcontaminated sites. Petroleum Technology Alliance of Canada (PTA) Calgary, AB.

Gibb A, Chu A, Wong RCK, Goodman RH (2001). Bioremediation kinetics of crude oil at $5^{\circ} \mathrm{C}$. J. Environ. Eng. 127(9):818.

Gibson DT, Sayler GS (1992). Scientific foundation for bioremediation:Current status and future needs: American Academy of Microbiology, Washington DC. 1-24.

Gibson DT, Subramanian V (1984). Microbial degradation of aromatic hydrocarbons. In Gibson D T (ed), Microbial degradation of organic compounds. Marcel Dekker, inc., New York. 182-252.

Habe $H$, Chung JS, Kato $H$ (2004). Characterization of the upper pathway genes for fluorene metabolism in Terrabacter sp.strain DBF63. J. Bacteriol 186:5938-5944.

Hahn WJ, Loehr RC (1992). Biological treatment of petroleum oily sludge in proceedings of the Permian Basin oil and gas recovery conf. Texas, SPE-Soc. Of Pet. Engineers.

Heitkamp MA, Franklin W, Cerniglia CE (1988a) Microbial metabolism of polycyclic aromatic hydrocarbons: Isolation and characterization of a pyrene-degrading bacterium. Appl. Environ. Microbiol. 54:25492565.

Heitkamp MA, Freeman JP, Miller DW, Cerniglia CE (1988b). Pyrene degradation by a mycobacterium sp:identification of ring oxidation and ring fission products. Appl. Environ. Microbiol 54:2556-2565.

Hejazi RF, Husain T, Khan FI (2003). Landfarming operation of oil sludge in arid region-human health risk assessment. J. Hazard. Materi. B99:287-302.

Huesemann MH, Moore KO, Johnson RN (1993). The fate of BDAT polunuclear aromatics compounds during biotreatment of refinery API oil separator sludge Environ. Proj. 12:30-38.

Idris A, Ahmed M (2003). Treatment of polluted soil using bioremediation - A review. Faculty of Chemical and Environmental Engineering, University of Putra, Malaysia. 1-18.

Iglesias-Groth S, Manchado A, Rebolo R, Gonzalez Hernandez JI, Garcia-Hernandez DA, Lambert DL ( 2010). A search for interstellar anthracene toward the Perseus anomalous microwave emission region. Bibcode:2010arXiv1005.4388I.

Johnson CR, Scow KM (1999). Effect of nitrogen and phosphorus addition on phenanthrene biodegradation in four soils. Biodegradation. 10:43 - 50.

Jose AM, Jose LM, Teresa H, Carlos G (2006). Bioremediation by composting of heavy oil refinery sludge in semiarid conditions. Biodegrad. 17:251-261.

Kanaly RA, Harayama S (2000). Biodegradation of high-molecular weight polycyclic aromatic hydrocarbons by bacteria. J. Bacteriol. 182, 2059-2067.

Karamalidis AK, Voudrias EA (2001). Stabilization/Solidification of oil refinery sludge: immobilization of heavy metals. $7^{\text {th }}$ conference of environmental Science and Technology Ermonpolis, Syros Island, Greece.

Kasuga K, Habe H, Chung JS, Yoshida T, Nojiri H, Yamane H, Omori T (2001). Isolation and characterization of the genes encoding a novel oxygenase component of angular dioxygenase from the grampositive dibenzofuran-degrader Terrabacter sp.strain DBF63. Biochem Biophy Res Co. 283:195-204.

Kim S, Choi DH, Sim DS, Oh Y (2004). Evaluation of bioremediation effectiveness on crude oil-contaminated sand. Chemosphere 59(6):845-852.
Kosaric N (2001). Biosurfactant for soil bioremediation. Food, Technol. Biotechnol. 39 (4) 295-304

Kriipsalu M, Marques M, Nammari DR, Hogland W (2007). Biotreatment of oily sludge:The contribution of amendment material to the contents of target contaminants and the biodegradation dynamics. J. Hazard. Mat. $148(3): 616$ - 622.

Lajoie CA, Layton AC, Sayler GS (1994). Cometabolic oxidation of polychlorinated biphenyl in soil with a surfactant-based field application vector. Appl. Environ. Microbiol. 60 (8):2826- 2833.

Laskova T, Zabukas V, Vaitiekunas P (2007). Influence of meterological conditions on volatile organic compound spread in the atmospheric boundary layer. J. Environ Eng. Landscape Manag. 15 (3):135-143.

Lazar I, Dobrota S, Voicu A (1999). Microbial degradation of waste hydrocarbons in oily sludge from some Romanian oil fields. J.Petroleum Sci Eng. 22:151-160.

Le Marchand L, Hankin JH, Pierce LM, Sinha R, Nerurkar PV, Franke AA, Wilkens LR, Kolonel LN, Donlon T, Seifried A, Custer LJ, LumJones A, Chang W (2002).Well-done red meat, metabolic phenotypes and colorectal cancer in Hawaii. 2002 Sep Mutation Res. 30:506507:205-14.

Leahy JG, Colwell RR (1990). Microbial degradation of hydrocarbons in the environment. Microbiol. Rev. 3:305.

Lees ZM (1996). Bioremediation of oil-contaminated soil:A South African case study. A PhD thesis submitted to the University of Natal, Pietermaritzburg, South Africa.

Leung M (2004). Bioremediation:Techniques for Deaning up Emess. J. Bioteach. 2:18- 22

$\mathrm{Li}$ CT, Lee WJ, Mi HH, Su CC (1995). PAH emission from the incineration of waste oil sludge and PE plastic mixtures. Sci. Total Environ. 170, 171-183.

Liang Y, Gardner DR, Miller CD, Chen D, Anderson AJ, Weimer BC, Sims RC (2006). Study of biochemical pathways and enzymes involved in pyrene degradation by Mycobacterium sp. strain KMS. Appl Environ Microbiol 72:7821-7828.

Liu T, Hou J, Zuo Y, Bi S, Jing J (2011). Isolation and characterization of a biosurfactant producing bacterium from Daqing oil-contaminated site. Afr. J. Microb. Res. 5(21):3509-3514.

Liu W, Luo Y, Teng Y, Li Z, Ma L Q (2010). Bioremediation of oily sludge-contaminated soil by stimulating indigenous microbes. Environ Geochem Health. 32:23-29.

Loser C, Seidel H, Zehnsdarf A, Stoltmeister U (1998). Microbial degradation of hydrocarbons in soil during aerobic/anaerobic changes and under purely aerobic condition. Appl. Microbiol. Biotechnol. 49:631.

Mac Naughton SJ, Stephen JR, Venosa AD, Davis GA, Chang YJ, White DC (1999). Microbial population changes during bioremediation of an experimental oil spill. Appl. Environ. Microbiol. 65:3566.

Machin-Ramirez, CAI, Okoh DK, Morales M, Mayolo-Deloisa R, Quintero, Trejo-Hernaindez (2008). Slurry-phase biodegradation of weathered oily sludge waste. Chemosph. 70:737-744.

Mahmoud S (2004). Novel technology for sustainable petroleum oil sludge management:Bio-neutralization by indigenous fungal-bacterial co-cultures. A Masters Degree submitted to the Department of Building, Civil and Environmental Engineering at Concordia University, Montreal, Quebec, Canada.

Maier RM (2003). Biosurfactant:Evolution and diversity in bacteria. Adv. Appl. Microbiol. 52:101-121.

Marin Millản JA (2004). Bioremediaciỏn, mediante tẻcnicas biolỏgicas, de hidrocarburos contenidos en lodos de refinerỉa. Experinecias en clima semiảrido. Doctoral thesis, Murcia University.

Mehrashi MR, Haghighi B, Shariat M, Naseri S, Naddafi K (2003). Biodegradation of petroleum hydrocarbon in soil. Iran. J. public Health. 32 (3):28-32.

Meyer S, Steinhart H (2001). Fate of PAHs and hetero-PAHs during biodegradation in a model soil/compost-system:Formation of extractable metabolites. Water Air Soil Poll. 132:215-231.

Micky V (2006). Microbial bioremediation of polycyclic aromatic hydrocarbons (PAHs) in oily sludge wastes. Pp:1-12.

Milne BJ, Baheri HR, Hill GA (1998). Composting of heavy oil refinery sludge. Environ. Progr. 17:24 - 27.

Mishra S, Jyoti J, Kuhad RC, Lai B (2001). In situ bioremediation potential 
of an oil sludge-degrading bacterial consortium. Curr. Microbiol. 43:328-335

Moody JD, Freeman JP, Doerge DR, Cerniglia CE (2001). Degradation of phenanthrene and anthracene by cell suspensions of Mycobacterium sp.strain PYR-1. Appl Environ Microbiol 67:14761483.

Mueller JG, Lantz SE, Blattmann BO, Chapman PJ (1991). Bench-scale evaluation of alternative biological treatment processes for the remediation of pentachlorophenol- and creosote- contaminated material: solid-phase bioremediation. Environ. Sci. Technol. 25:10451055.

Mukherjee AK, Das K (2005). Correlation between diverse cyclic lipopeptides production and regulation of growth and substrate utilization by Bacillus subtilis strains in a particular habitat. FEMS Microbiol. Ecol. 54:479-489.

Namkoong WE, Hwang JP, Choi J (2002). Bioremediation of dieselcontaminated soil with composting. Environ. Pollution. 119:23.

Okieimen CO, Okieimen FE (2005). Bioremediation of crude oil-polluted soil - Effect of poultry droppings and natural rubber processing sludge application on biodegradation of petroleum hydrocarbon. Environ Sci. 12(1):001 - 008.

Oolman T, Baker RR, Renfro NL, Marshall GE (1996). Refinery uses bioslurry process to treat RCRA wastes. Hydroc. Process. 71 - 76.

Parẻ T, Dinel H, Schnitzer M (1999). Extractability of trace metals during co-composting of biosolids and municipal solid wastes. Biol. Fert. Soils. 29:31- 37.

Paulauskiene T, Zabukas V, Vaitiekunas P (2009). Investigation of volatile organic compound (VOC) emission in oil terminal storage Tank Park. J. Environ Engnr. Landscape Manage. 17 (2):81-89.

Pereira-Neta JT (1987). On the treatment of municipal refuse and savage sludge using aerated static pile composting- A low cost technology approach. PhD. Dissertation. Leeds University. U.K.

Phillips TM, Liu D, Seech AG, Lee H, Trevors JT (2000). Monitoring bioremediation in creosote-contaminated soils using chemical analysis and toxicology tests. J. Ind. Microbiol. Biotechnol. 65:627.

Piotrowski MR (1991). Bioremediation of hydrocarbon contaminated surface water, groundwater and soils:The microbial ecology approach. In Kostecki, PT, Calabrese, EJ (Eds). Hydrocarbon contaminated soils and groundwater:Analysis fate Environmental and public health effects remediation. Lewis publisher, Chelsea, Michigan. 1.

Piskonen R, Itävaara M (2004). Evaluation of chemical pretreatment of contaminated soil for improved PAH bioremediation. Appl. Microbiol. Biotechnol. 65:627.

Plaza GA, Pacwa-Plociniczak M, Piotrowska-Seget Z, Cameotra SS (2011). Environmental applications of biosurfactants:Recent advances. Int. J. Mol. Sci. 12:633-654.

Radetski CM, Mater L, Sperb RM, Madureira LAS, Rosin AP, Correa AXR (2006). Proposal of a sequential treatment methodology for the safe reuse of oil sludge-contaminated soil. J. Hazard. Mat. $B$ 136:967-971.

Reid BJ, Jones KC, Semple KT, Fermor TR (2000). Bioremediation potentials of PAHs in compost. In Leeson A, Alleman BC (eds), Bioremediation Technologies for polycyclic aromatics hydrocarbon compounds. Battelle, Columbus. 25-30.

Research triangle institute (1999). Toxicological profile for total petroleum hydrocarbons (TPH) prepared for US Department of health and human services.

Ri-He P, Ai-Sheng X, Yong X, Xiao-Yu F, Feng G, Wei Z, Yong-Sheng $\mathrm{T}$, Quan-Hong $Y$ (2008). Microbial biodegradation of polyaromatics hydrocarbons. Shanghai key laboratory of agricultural genetics and breeding, agro-biotechnology research institute, shanghai academy of agricultural sciences, shanghai china. Review. FEMS Microbiol Rev. 32:927-955.

Ron EZ, Rosenberg E (2001). Natural roles of biosurfactants. Environ. Microbiol. 3:229-236.

Salameh MF, Kabrick RM (1992). Treatment of petroleum oily sludge in liquid/solid contact reactors-results of batch testing. In:Proceedings University. of the $46^{\text {th }}$ Ind. Waste Conf., West Lafayette, Indiana, Purdue.

Shie J, Lin J, Chang C, Wu C, Lee D. Chang C, Chen Y(2004). Oxidative thermal treatment of oil sludge at low heating rates. Energy
Fuel 18:1272-1281.

Shiohara K, Diehl SV, Borazjani H (2001). Use of commercial surfactants for enhanced biodegradation of organic woodpreservative contaminated processwater. In proceedings of the 2001 Mississipi Water Resources Conference. Raymond, Mississipi, USA.

Sidney D (2008). Agency for toxic substances and diseases registry and national centre for environmental health.

Sim L, Ward OP (1997). Production characterization of a biosurfactant isolated from Pseudomonas aeruginosa UW-1. J. Ind. Microbiol. Biotechnol. 19:232.

Singer ME, Finnerty WR (1984). Microbial metabolism of straight-chain and branched alkanes. In: Atlas RM (Eds) Petroleum microbiology. Macmillan New York. 1-55

Singh C, Lin J (2010). Bioaugmentation efficiency of diesel degradation by Bacillus pumilus JL3 and Acinetobacter calcoaceticus LT1 in contaminated soil. Afr. J. Biotech. 9 (41):6881-6888.

Singh A, Mullin B, Ward O (2001). Reactor-based process for the biological treatment of petroleum wastes. Petrotech, petrozyme technologies inc.

Soriano AU, Pereira N Jr (2002). Oily sludge biotreatment. Biotech and Ecosys. Dept. Petro. Res. Centre, $9^{\text {th }}$ Annul Int'l Petrol Brazil.

Srinivasarao-Naik B, Mishra IM, Bhattacharya SD (2011). Biodegradation of total petroleum hydrocarbons from oily sludge. Bioremed. J. 15 (3):140-147.

Suflita JM, Horowitz A, Shelton DR, Tiedje JM (1982). Dehalogenation:A novel pathway for the anaerobic biodegradation of haloaromatic compounds. Sci. 218:1115.

Sutherland JB (1992). Detoxification of polycyclic aromatic hydrocarbons by fungi. J. Ind. Microbiol. 9:53-62.

Sutherland JB, Rafti F, Khan AA, Cerniglia CE (1995). Mechanisms of polycyclic aromatic hydrocarbon degradation. In Microbial transformation and degradation of toxic organic chemicals (Eds) Young, LY, Cerniglia CE. Wiley Liss, New York. 269-306.

Swindell CM, Aelion CM, Pfaender FK (1988). Influence of minerals and organic nutrients anaerobic biodegradation and the adaptation response of surface microbial communities. Appl. Environ. Microbiol. 54:212-217.

Tabuchi K, Matu-ura K, Kawakani S, Shiratori T, Saitoh T (1998). Remediation and recycling of the soil contaminated with petroleum hydrocarbon. Metall. Rev. MMIJ. 1:14 - 25.

Taiwo EA, Otolorin JA (2009). Oil recovery from petroleum sludge by solvent extraction, petrol. Sci. and Technol. 27:8, 836-844.

Tate SM, Winegardner DL (1995). Soil Microbiology. John Wiley and Sons, Inc., New York. 398.

TERA (2008). "Peer Consultation on Relationship between PAC Profile and Toxicity of Petroleum Substances" (API Report), http://www.tera.org/peer/API/APIWelcome.htm, accessed 28 Oct 2009 and "Report of the Peer Consultation on Relationship between PAC Profile and Toxicity of Petroleum Substances Volume I" (TERA peer review) http://www.tera.org/peer/API/PAC MEETING REPORT Final.pdf, accessed 28 Oct 2009.

Udotong IR, Udotong IJ, Inam E, Kim K (2011). Bioconversion of crude oil production into soil conditioner Using sawdust as Organic amendment. Geosyst. Engr. 14 (2):51-58.US EPA method 3541.

USEPA (1997). EPA's contaminated sediment management strategy. Office of water and solid waste. USEPA, Washington D C.

van Hamme JD, Singh A, Ward OP (2003). Recent Advances in petroleum microbiology. Microbiol. Mol. Rev. 67:649.

Van Veen JA, Van Overbeek LS, Van Elsas JD (1997). Fate and activity of Microorganisms introduced into soil. Microbial. Mol. Biol. Rev. 61:121-135.

Vila J, Lopez Z, Sabate J, Minguillon C, Solanas AM, Grifoll M (2001). Identification of novel metabolites in the degradation of pyrene by Mycobacterium sp. strain AP1:actions of the isolate on two- and three- ring polycyclic aromatic hydrocarbons. Appl Environ Microbiol. 67:5497-5505.

Vinas M, Sabate J, Espuny MJ, Solanas AM (2005). Bacterial community dynamics and polycyclic aromatic hydrocarbon degradation during bioremediation of heavily creosote-contaminated soil. Appl. Environ. Microbiol. 71:7008.

Walter U, Beyer M, Klein J, Rehm HJ (1991). Degradation of pyrene by Rhodococcus sp. UW1. Appl. Microbiol. Biotechnol. 34:671-676. 
Wang J, Yin J, Ge L, Shao J, Zheng J (2010). Characterization of oil sludge from two oil fields in China. Energy Fuel. 24:973-978.

Ward W, Singh A, van Hamme J (2003). Accelerated biodegradation of petroleum hydrocarbon waste. J. Ind. Microbiol, Biotechnol. 30:260.

Watanabe K (2002). Linking genetics, physiology and ecology:an interdisciplinary approach for advancing bioremediation. J. Biosci. Bioeng. 94 (6):557-562.

Wattiau P, Bastiaens L, van Herwijnen R, Daal L, Parsons JR, Renard ME, Springael D, Cornelis GR (2001). Fluorene degradation by Sphingomonas sp. LB126 proceeds through protocatechuic acids:a genetic analysis. Res Microbiol. 152:861-872.
Wright RA, Noordhius (1991). The treatment and disposal of oil solids, proceedings of the first international conference on health, safety and environment. In oil and gas exploration and production part. 2:521526.

Wong JWC, Fang M, Zhao Z, Xing B (2004). Effects of surfactants on solubilisation and degradation of phenenthrene under thermophilic conditions. J. Environ. Qual. 33:2015-2025.

Zhou E, Crawford RL (1995). Effect of oxygen, nitrogen and temperature on gasoline biodegradation in soil. Biodegrad. 6:127140. 